\title{
Proceso evolutivo de los rituales de conquista en España
}

\author{
"¿No eres leal? / Español soy, con eso he respondido" \\ "O se hacen todos cristianos, /o mueren sin más tardanza"
}

(En parlamentos tradicionales de autor anónimo)

En los albores del siglo xxI, a lo largo del continente americano, el sur del europeo e islas atlánticas, mediterráneas y asiáticas, en varios cientos de poblaciones que formaron parte del imperio español se siguen representando anualmente las luchas por la conquista de un bando sobre otro, en lo que configura un complejo festivo que se puede considerar tan característico de la cultura hispánica como lo es la corrida de toros.

En esencia, se trata de uno de los espectáculos que se integran en la estructura ritual de muchas fiestas comunitarias, normalmente para realzar los actos litúrgicos. Presentan una gran rigidez formal, con un mecanismo expresivo de tipo teatral, basado en una cadena de situaciones dramáticas, siendo las acciones gestuales a menudo acompañadas por diálogos y música dentro de un entorno escénico. Cada bando, compuesto por uno o varios hombres organizados jerárquicamente, se enfrenta al bando opuesto para dominarlo y apoderarse de un bien colectivo. El resultado de la confrontación, prefijado de antemano, muestra la victoria de los béroes sobre sus enemigos, con lo que se reafirman los valores normativos entre los actores y espectadores, miembros de la misma comunidad. No suele tener significación especial en qué bando se lucha.

Dentro de este vasto ámbito de lo que considero representaciones rituales de conquista (con modalidades extendidas por la mayor parte de las culturas del mundo), en lo que se refiere a las hispánicas parece evidente que sus modelos inspiradores se tienen que encontrar en la Península Ibérica, la Hispania de la Antigüedad. Para buscar las claves interpretativas de un fenómeno cultural de tal amplitud geográfica y persistencia histórica, con demostrable unidad estructural, y diversidades argumentales en las que tienen cabida el rapto de una doncella por el dragón, la domesticación del oso salvaje, un desembarco turco en Yucatán o que Pizarro decapite al inca Atahualpa; al tratarse todas de variantes hispánicas, creo conveniente proceder al análisis comparativo de los fes- 
tejos españoles contemporáneos y al rastreo de la evolución histórica de sus formas expresivas antes de intentar descodificar sus significados simbólicos, que no todos resultan fáciles de interpretar.

\section{ANÁLISIS EN LA ESPAÑA ACTUAL}

Las representaciones rituales de conquista en la España posterior a la muerte del dictador Franco han ido aumentando en número, ampliando la gama de bandos enfrentados con la rememoración de hechos históricos, como las guerras entre romanos y cartagineses - que se celebran en Cartagena desde 1990 e incluyen entre sus actos centrales la "boda de Aníbalı; el rechazo de un desembarco inglés —en la isla de Fuerteventura (desde 1986) y la ría de Ferrol (1992)—; y, también en la costa gallega, la invasión de los vikingos y su victoria sobre las tropas del arzobispo de Santiago (1973). Al mismo tiempo, se está imponiendo el aspecto más lúdico, sensual y carnavalesco de estos rituales sobre la seria vertiente ideológica y religiosa, que hasta hace pocas décadas los impregnaban.

Nos hallamos pues, ante un fenómeno cultural vivo, expansivo y en plena transformación, lo que dificulta su análisis. Para efectuarlo, lo primero debe ser su clasificación, pero tampoco es una empresa sencilla, ya que hay luchas rituales en las que no es evidente su pertenencia al conjunto, aunque se las pueda incluir. Por ello, comencemos el estudio de este universo festivo por un subconjunto que se puede definir por su carácter de rememorar episodios épicos de la historia local. Aquí entrarían las diversas reconstrucciones históricas (a menudo salpicadas de incongruencias y deformaciones) en las que uno de los bandos en presencia, el de los héroes, está constituido por los nativos - genéricamente los "españoles", por esencia "cristianos"-, mientras que el opuesto, el de los enemigos, corresponde a diversos "extranjeros", $\tan$ cercanos como los "portugueses" (también católicos), "franceses" (los ateos de la época revolucionaria), "ingleses" (cristianos heréticos) y los "moros" de Marruecos, o tan lejanos como los "turcos" (también musulmanes) y los "vikingos" (paganos), lo que implica un carácter étnico del conflicto, que, salvo en el caso de los fronterizos portugueses y el reciente ritual de Cartagena, también es religioso. Dentro de este subconjunto “épico-étnico-religioso-histórico" ${ }^{1}$ encontramos que, de un modo avasallador, la clase actualmente

1 Que concuerda con lo que Jesús Jáuregui y Carlo Bonfiglioli consideran como definitorio para las danzas de conquista: "La formación de dos grupos cuyo antagonismo se fundamenta - por medio de la escenificación de un combate- en la con- 


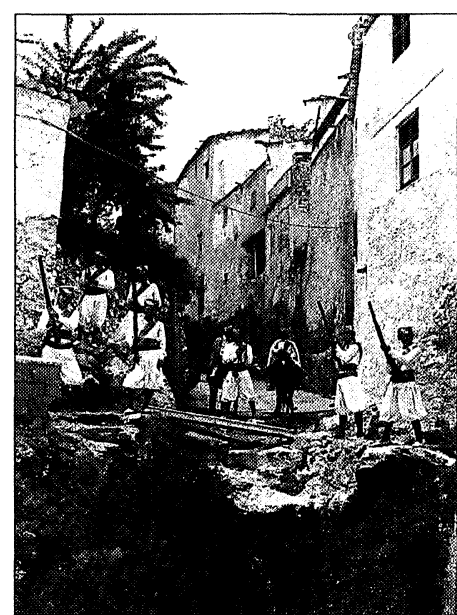

FIG. 1.-En las Alpujarras se rememora con gran realismo la rebelión de los moriscos granadinos en 1568 . predominante resulta ser la de las danzas, relaciones o embajadas de Moros y Cristianos, por lo que puede ser operativo comenzar el análisis por ellas.

Para abordarlas, será útil someterlas a diferentes parámetros divisorios:

1.-Fuentes de inspiración bistórica específica

a) Cruzadas o "reconquista" peninsular (desde el s. IX al XV).

b) Rebelión de los moriscos peninsulares (en el s. XVI).

c) Guerras contra el imperio turco (en el s. XVI).

d) Saqueos costeros por piratas berberiscos (ss. XVI-XVIII).

e) Guerras de Marruecos (ss. XIX-XX).

En la mayoría de los casos se entremezclan personajes y situaciones de modo anacrónico, por lo que apenas tiene relevancia este criterio.

\section{2.-Características de la representación teatral \\ * Luchas mímicas sin parlamentos. \\ ** Danzas habladas. \\ *** Coloquios con escaramuzas. \\ **** Dramas con escenografía. \\ ***** Alardes o desfiles con embajadas y} castillo.

Aquí se retoma el criterio representacional formulado por uno de los primeros investigadores del tema en España, G. Guastavino ${ }^{2}$, ampliando su división según el nivel de complejidad teatral de las representaciones rituales. A menudo, los cambios

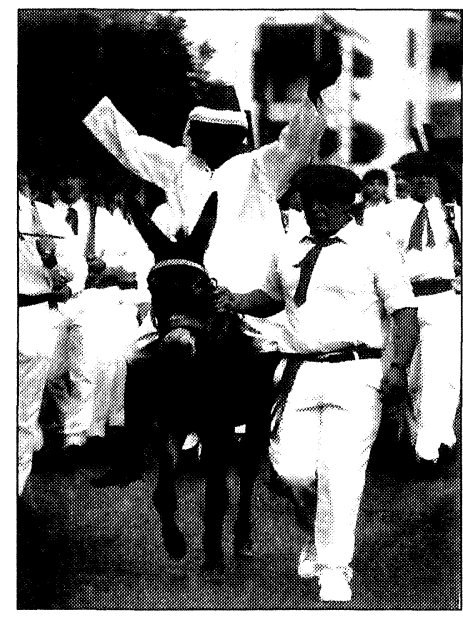

FIG. 2.-En la guipuzcoana Antzuola, la soldadesca cautiva al mítico moro Abderramán.

quista, recuperación o defensa de un territorio", en el minucioso y amplio estudio de campo coordinado por ellos, Las danzas de conquista, tomo I: México contemporäneo (México: Fondo de Cultura Económica, 1996), p. 12.

2 Las fiestas de Moros y Cristianos y su problemática (Madrid: CSIC, 1969), pp. 6-20. 
socio-económicos y culturales en la localidad repercuten en la importancia que se otorga a los actos de las fiestas patronales, pudiendo aumentar o disminuir en espectacularidad y pasar de un nivel a otro dentro de esta escala, según el presupuesto disponible por los organizadores, que redundará en el número de actores, su indumentaria, la escenografía, la coreografía y el acompañamiento musical. Estas dimensiones escénicas podrían constituir campos semánticos, pero actualmente veo poco operativa la búsqueda de su significación, debido a las diversas y fuertes influencias que soportan. Hay poblaciones que ejercen como foco de irradiación y son imitadas.

\section{3.-Distribución geográfica}

Hay que tener en cuenta que las anteriores características formales suelen encontrarse en la misma área territorial, por lo que se pueden formar familias de representaciones. Afinando más, se pueden localizar subfamilias o núcleos comarcales con elementos comunes. Así, en la España actual se pueden establecer las siguientes familias de Moros y Cristianos con sus respectivas subfamilias o áreas festivas:

a) Alardes valencianos: Las fiestas más conocidas, destacan por los miles de actores, riqueza de su vestuario, espectacularidad de sus desfiles, gran aparato escénico, derroche de pólvora y ambiente profano.

Áreas: Zona alcoyana, Sierra de Utiel, Alto Turia.

b) Dances aragoneses: danzas de palos o espadas, conectadas con una acción teatral sin escenografía, dividida en: pastorada, ángel y demonio y soldadesca, con loa al patrono, ofrendas y mojiganga humorística.

Áreas: Ribera del Ebro, Alto Aragón, Pirineos, Sierra de Gúdar.

c) Relaciones andaluzas: superposición de temas narrativos con extensos textos, victoria inicial de los moros, fuerte componente religioso, juego de banderas, caballos, escaramuzas, pocos medios, muy rurales.

Áreas: Alpujarra, Altiplanicie de Guadix-Baza, Sierra de los Filabres, Río Almanzora, Ajarquía, Serranía de Ronda, Sierra Mágina.

d) Dichos conquenses: coloquios con escaramuzas o guerrillas, sátiras, convite a cargo del cura y misa de difuntos.

Áreas: La Mancha, Serranía del Júcar.

e) Embajadas gallegas: textos ahistóricos en gallego, sencillez de recursos, muy rurales.

Áreas: Valle de Laza, Tierra de Trives.

f) Desembarcos baleares: Reconstrucción del histórico rechazo de piratas turcos, escaramuzas sin parlamentos ni apenas escenografía, mucha pólvora, desfile de carrozas.

Área: Costa mallorquina. 

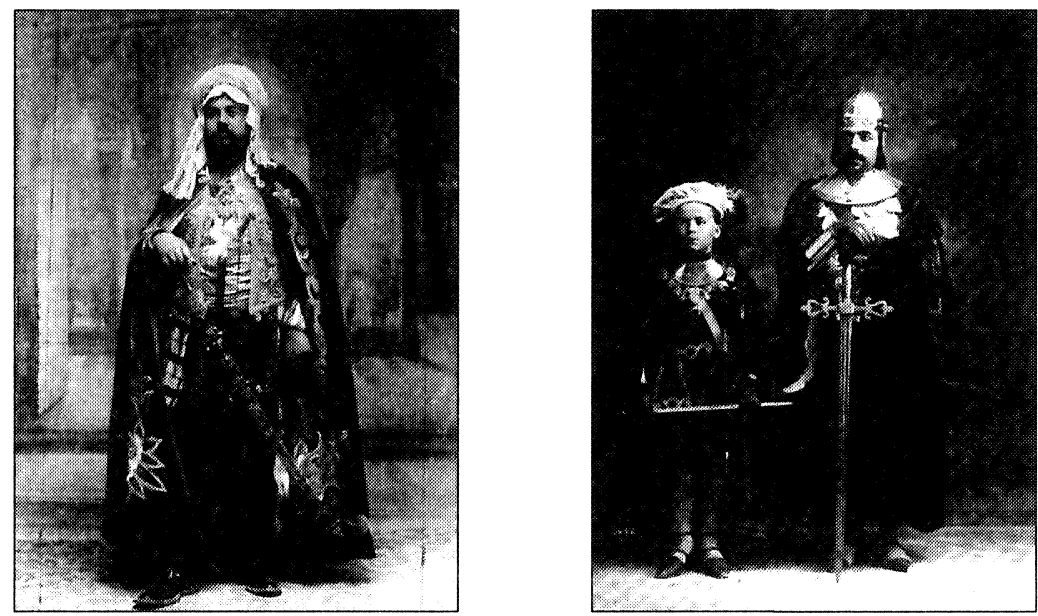

FIGs. 3 y 4.-Capitanes moro y cristiano de una comparsa de las fiestas de Alcoy (Alicante) a principios de siglo.

g) Luchas ibéricas: Diversos modelos festivos que se ejecutan en gran número de localidades dispersas. Sin homogeneidad.

Esta vía geográfica o mesológica, que es la utilizada por la mayoría de los investigadores que se han ocupado del tema, ofrece claridad en la diferenciación de esquemas festivos, pero plantea un grave problema operativo, ya que en la misma zona pueden coexistir modelos distintos.

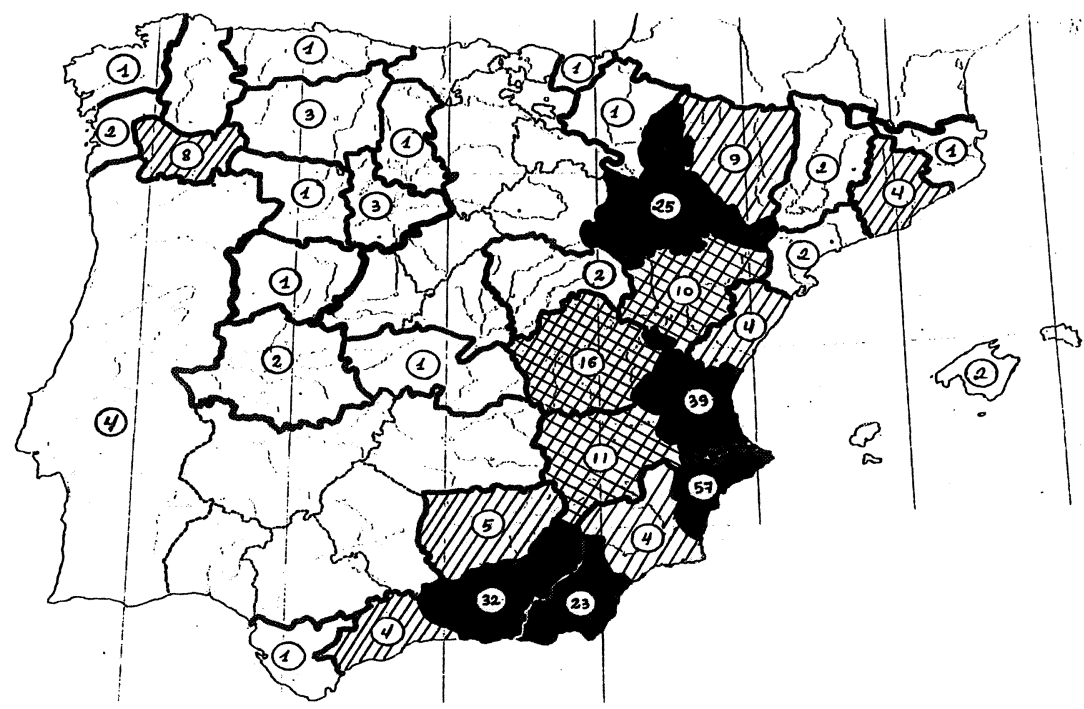

GRÁFICO 1.-Número y distribución de las representaciones rituales de conquista que hemos registrado en la España contemporánea. 
De hecho, hay un esquema, el de los alardes de Alcoy, que se está expandiendo por fiestas de Almería, Granada, Cuenca, Murcia y Albacete, modificándose su modo tradicional de festejar a los patronos. La existencia contemporánea de rituales de conquista por casi toda la geografía del estado español implica que se deben formular más criterios divisorios que puedan facilitar una clasificación bien precisa.

Respecto a las vías de trasmisión, se podrían vincular con los movimientos repobladores y con la trashumancia pastoril que seguía las rutas de la mesta ${ }^{3}$. El más relevante papel en el proceso constructivo y la difusión de estos rituales correspondió al reino de Aragón, posiblemente desde los monasterios benedictinos pirenaicos.

\section{4.- La estructura argumental}

Queda una última vía clasificatoria: la que proporcionan, cuando existen, los propios parlamentos o textos de las representaciones. Si les aplicamos la técnica de análisis argumental diseñada por W. Propp ${ }^{4}$, modificando su concepto de "función" en los cuentos maravillosos por el de "acciones significativas en el desarrollo de la representación teatral", al tratarse de otro medio de comunicación - entendiendo como tales tanto las que se expresan por movimientos con sentido narrativo como los diálogos que modifican el nivel de la confrontación y los que establecen relaciones con la esfera de lo sobrenatural-, veremos que cada unidad sintagmática o eslabón narrativo mínimo está compuesto por dos clases de elementos: unos variables, que concretan y diferencian desarrollos argumentales semejantes (como son los atributos de los personajes, los objetos materiales y los símbolos), y otros fijos o permanentes que constituyen la estructura básica del argumento. Así, que un cristiano cautive a un moro o que un mexicano lo haga con un francés, son diversas expresiones de la misma acción: el cautiverio del enemigo por el héroe.

Sentada esta premisa, he identificado 24 acciones significativas con las que se pueden materializar todos los argumentos, y por lo tanto todas las versiones, tanto de las danzas de Moros y Cristianos como de Conquista

3 No se olvide que el rey David fue pastor, y de algún modo el héroe o patrono de los pastores. Una significativa sustitución simbólica de su bíblico duelo sucedió en Toledo en 1622, cuando los jesuítas festejaron la canonización de sus primeros santos con un espectacular combate en el que el pastor san Ignacio vencía al malvado LuteroGoliat, y le degollaba, consiguiendo así a la princesa, alegoría de "la gloria de Dios". En la anónima Breve relación de las fiestas que se bicieron en la ciudad de Toledo... (Toledo, 1622), ff. 20-23.

4 Como efectúo en mi libro Fiestas de Moros y Cristianos en Granada (Granada: Diput. Prov. de Granada, 1988). 
en general, y que muy resumidamente nos dan el siguiente argumento total de las representaciones de conquista:

(Introducción o situación inicial de la representación)

Visión o sueño presagioso - Aparición sobrenatural

Negociación - Entrega de carta - Reto (Embajadas)

Descanso tras el reto - Debate interno - Juego de azar

Alianza de ejércitos - Milagro

Herida - Curación

Incidente amoroso - Traición

Súplica al patrono celestial

Batalla por un objeto [con / sin ayuda sobrenatural]

Muerte - Entierro - Resurrección

Prisión o cautiverio - Apropiación de atributos - Liberación

Conversión o despojo - Premio o recompensa.

(Integración de los dos bandos que da fin a la representación)

A partir de esta cadena sintagmática, se obtienen todas las variantes con sólo suprimir algunas acciones y cambiar otras de orden. Agrupándolas por afinidades, eliminando las secundarias y quedándonos con las básicas, se puede llegar a una fórmula sintética concentrada así:

[introducción] - Reto - Súplica - Batalla (por un objeto) - Prisión/despojo

El núcleo narrativo básico se puede enunciar así:

* Aparece el enemigo con intención de apoderarse de un bien.

- Exige su entrega a los héroes y les desafía.

- Súplica de los héroes para obtener la ayuda sobrenatural.

- Batalla por el bien en litigio, con/sin colaboración sobrenatural.

- Cautiverio del enemigo, que se integra en el bando heroico.

* Término de la representación, con el enemigo neutralizado (convertido o prisionero, a veces tras la muerte de su jefe) y los héroes disfrutando del objeto disputado.

Hay que tener en cuenta que en las danzas o bailes de conquista americanos, los vencedores son los invasores españoles, que gozan de los opuestos valores de enemigos (-) portadores de la fe cristiana (+).

Cuando se trata de un relato bi-secuencial, con la victoria inicial del enemigo en la primera batalla (con el consiguiente cautiverio del castillo, del santo y a menudo de un héroe) y su decisiva derrota en la segunda, lo que se produce es un desdoblamiento de la acción de la batalla. Hay registrados casos de numerosas batallas en la representación.

Este núcleo del desarrollo argumental de las representaciones rituales de conquista, exige para su interpretación que se incluya dentro del con- 
texto ritual en el que se expresa y del que es un eslabón más, ya que el mero análisis formal de los textos no es suficiente. Al disponer de abundante documentación sobre el desarrollo genético de este ritual festivo, habrá que contar además con las aportaciones del estudio histórico-cultural de su evolución y de la etnografía referente a rituales emparentados y asimilados.

\section{5.-Los objetos de la batalla}

Desde el punto de vista de la morfología narrativa, los objetos o bienes en disputa y que constituyen el motivo fundamental de la confrontación ofrecen un enorme interés significativo, y merecen que se les dedique un estudio aparte, para obtener una clasificación formal según sus variantes:

a) Apoderarse de la imagen del milagroso patrono

Este grupo temático, que es el predominante, puede recordar los sucesivos robos de la estatua de Marduk, dios supremo de Babilonia; el cautiverio del Arca de la Alianza hebrea; numerosos mitos de la Grecia clásica, como los raptos del fuego por el titán Prometeo, del vellocino de oro por los Argonautas, de Proserpina por Plutón (dios del infierno) y de los rebaños de Gerión por el forzudo Hércules; así como el rapto de la bella Helena por los troyanos y otros cautiverios de doncellas que para Herodoto están en el origen de la historia europea ${ }^{5}$. Sin embargo, es una falsedad atribuir a los moros y turcos el deseo de posesión del santo, sabiendo que los musulmanes no rinden culto a las imágenes, por lo que se está ejerciendo con ellos una manipulación ideológica, para que encajen mejor en su papel de enemigos rituales. Lo que sí es cierto, es que a menudo destruyeron las reliquias que veneraban los cristianos peninsulares, como hizo el caudillo Almanzor hacia el año 1000 con los saqueos a las iglesias del Apóstol Santiago y de San Millán de la Cogolla, patronos de las huestes de la Cruz, que, así, se vieron doblemente humilladas.

b) La toma del castillo

Le sigue en número de casos, y suele tratarse del castillo de la propia localidad, que los héroes deben recuperar o conquistar, aunque también puede tratarse de una fortaleza genérica. Sus modelos inspiradores pueden ser las tomas de Troya, Jerusalén y Granada. Ya no quedan ejemplos del ciclo de la "defensa ante el asedio enemigo", basado en los cercos de Rodas, Malta y Viena. En cuanto al castillo como símbolo, posee una doble imagen: es la defensa contra los ataques enemigos, la protección militar;

5 HERODOTO, Los nueve libros de la Historia (Barcelona: Orbis, 1983), Libro I, pp. 11-13. 
pero es también la sede del poder, propiedad del señor al que entregar los tributos y que establece las normas.

c) Imponer la propia religión

Aunque es un motivo subyacente en todo este conjunto de representaciones, a veces es el único objetivo explícito de la lucha, bien por querer imponer la propia fe (como sucede en gran parte de las danzas de conquista americanas, aunque en ellas se expresa como motivo oculto apoderarse de las riquezas y mujeres de los indígenas) o por impedir que el cristiano celebre su fiesta litúrgica en honor del venerado patrono.

d) Tierras y bienes: el territorio

Este motivo se puede considerar implícito bajo el símbolo del castillo (terrenos a su alrededor), aunque a veces en los parlamentos se explicita que se combate por las casas y posesiones. La bandera comunitaria, que a veces es el objeto de la batalla, puede ser su símbolo. Al revés que en las danzas americanas, los invasores son derrotados y no consiguen su propósito.

e) Exigencia de un tributo

Variante de los dances del Pirineo aragonés, conectada con el ciclo temático carolingio, donde se piden "Sueldos" o dinero a los héroes, sometidos al poder territorial de los moros. Vestigios de tributos consistentes en la entrega de doncellas.

f) Rescate de la dama cautiva

Motivo que ha desaparecido de las representaciones españolas contemporáneas (salvo una aparición de la reina mora Floripez, raptada siendo cristiana y que regresa a su antigua fe) aunque tuvo enorme importancia en otras épocas. Hoy día sigue siendo el objeto de la batalla en representaciones de Portugal, Perú, Brasil y Croacia.

* Todos ellos, con o sin ayuda celestial, y si esta doble opción se expresa de modo binario con los signos + - resultaría: Batalla (objeto) +/- . Así, la manifiesta igualdad de fuerzas y valentía entre ambos bandos contendientes se decanta por el que disfruta del apoyo celestial, una especie de "juicio de Dios" que no sólo queda explícito en los parlamentos, sino que a menudo se recalca por la intervención de un ángel o del santo mediador ante la divinidad, papel que ocupa el patrono de la comunidad, que así demuestra la razón de su patrocinio.

En un nivel imaginario se encuentra el canónico despojo o conversión final de los moros que se integran en el bando de los héroes, cuando en la realidad sufrieron de la intolerancia de los vencedores, quienes no creían en la sinceridad de su conversión forzosa y terminaron expulsándolos de la Península a comienzos del s. XVII.

A menudo se suman explícitamente varios de los objetivos de la lucha, llegando a intervenir hasta cinco de ellos en alguna representación. 
Se puede elaborar un cuadro general que integre la dos últimas clasificaciones, basándonos en 113 representaciones que explicitan el objeto de la batalla:

$\begin{array}{lccccccc} & \text { Granada-Aragón } & \text { Valencia }- \text { Cuenca } \text { Resto Esp. } & = & \text { Total } \\ \text { Imagen: } & 15 & 8 & 6 & 9 & 3 & = & 41 \\ \text { Castillo: } & 3 & 4 & 7 & - & 7 & = & 21 \\ \text { Religión: } & - & 9 & 2 & 1 & 4 & = & 16 \\ \text { Territorio: } & 4 & 1 & 1 & - & 1 & = & 7 \\ \text { Tributo: } & - & 3 & - & - & 1 & = & 4\end{array}$

(las restantes, explicitan dos o más motivos)

$38+30+18+11+16=113$

En 24 casos, el $21 \%$ de la muestra, hay más de un objeto de la lucha, siendo la diada más numerosa la constituída por "imagen + castillo" (en 11 casos), mientras que el tributo es un motivo excluyente, ya que en ningún caso se presenta acompañado.

Hay que advertir que entre los alardes valencianos el objeto de la disputa casi siempre es el castillo, y ésta es la familia más numerosa (aunque por ser la mayoría de sus parlamentos unos textos que se renuevan cada año, y muy similares entre sí, apenas los he tenido en consideración a la hora de aplicar los análisis textuales), por lo que la toma del castillo se convierte de hecho en el tema predominante de la España contemporánea.

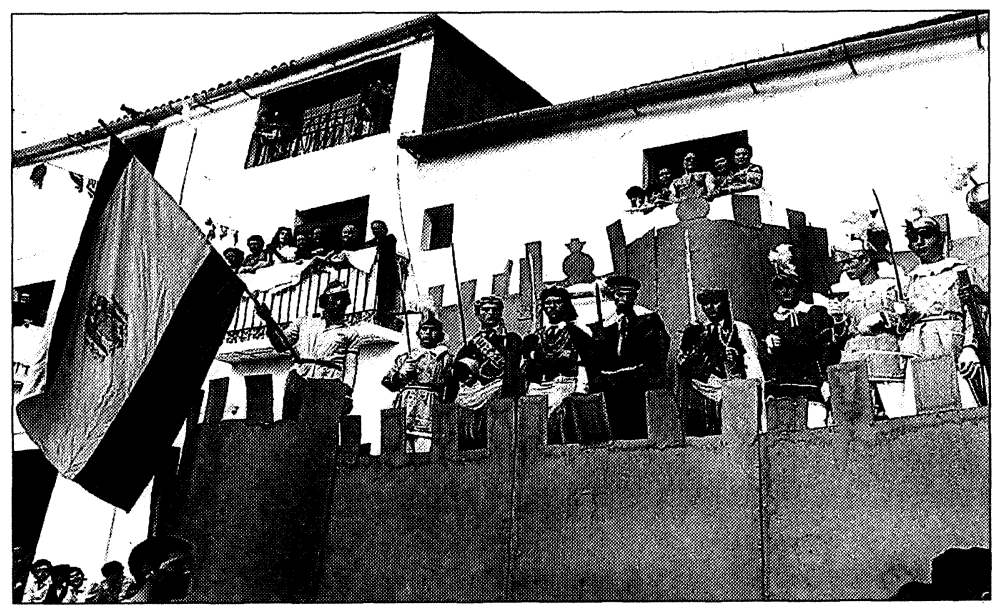

FIG. 5.-Castillo en disputa en la granadina Aldeire. 


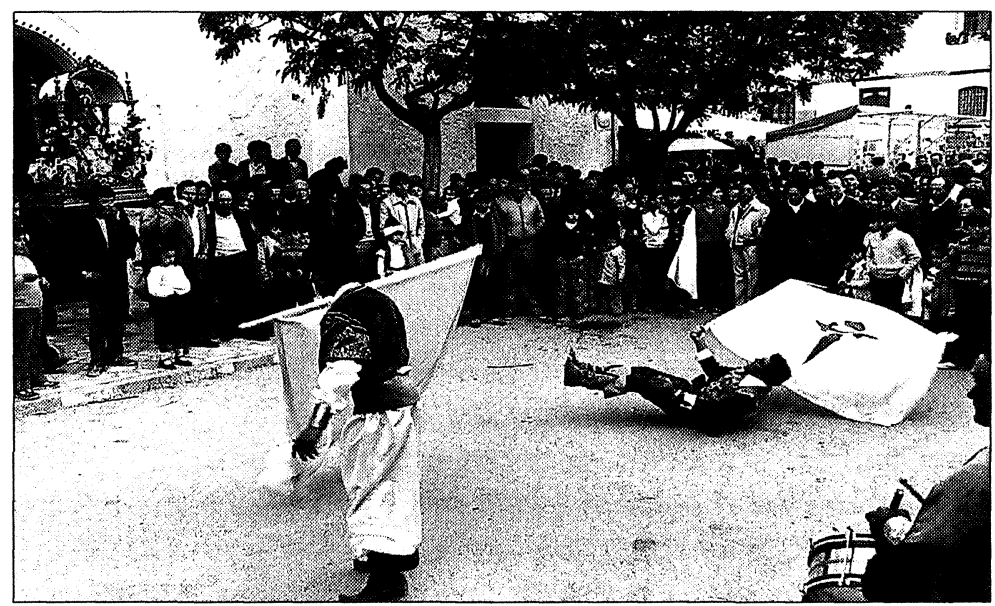

FIG. 6.-Las banderas pueden ser un simbólico objeto de la batalla (juego de los abanderados moro y cristiano en Zújar (Granada), en honor de su patrona que tratarán de cautivar los moros).

\section{ANTECEDENTES HISTÓRICOS EUROPEOS}

Mientras los juglares expandían por el Camino de Santiago los cantares de gesta con las hazañas del emperador Carlomagno, en las cortes peninsulares se celebraban pomposamente los acontecimientos dichosos. Así, la primera referencia que se posee respecto a una representación de esta clase es la danza de moros y cristianos que trabó un reñido combate, como parte de las diversiones con las que se festejó en 1150, en la recién conquistada Lérida, la boda entre el conde de Barcelona y la infanta de Aragón (que uniría políticamente a catalanes y aragoneses) ${ }^{6}$. Este conde obtuvo resonantes victorias en tierras francesas y andaluzas, consiguió que el Papa convocara una "cruzada" para tomar Tortosa en 1148, a la que acudieron gran número de caballeros franceses, y al siguiente año, con la toma de Lérida, culminó la "reconquista" de Cataluña.

Aproximadamente siglo y medio después, para festejar al rey de Aragón Jaime II en el día de su santo (que es el mismo nombre que Santiago), sus cortesanos:

vestidos unos de moros y otros de cristianos, tramando campal pelea [...] en donde se levantaba un castillo sobre un tablado, se dieron sendas cuchilladas, hasta que apareciendo en un brioso caballo blanco un capitán vestido de San Jaime, se

6 Dato indirecto recogido por Manuel SORIANO, Historia de la música española (Madrid, 1855), p. 125. 
puso de parte de los cristianos, y acuchillando a los moros, éstos se rindieron de rodillas a sus pies (terminando con su conversión y un baile conjunto) ${ }^{7}$.

Es muy interesante esta referencia, por tratarse del día del patrono del monarca, con la aparición del Apóstol a caballo; por la simbólica conquista de un castillo, por la conversión de los simulados moros y por el baile final "al son de los instrumentos de guerra".

A partir del último tercio del s. XIV, constan varios fastos monárquicos que muestran las variantes existentes en las luchas de conquista:

- 1373: En Valencia, por la boda del infante de Aragón con la princesa de Francia, varios gremios se encargaron de escenificar la pelea entre unos caballeros y un dragón ayudado por hombres salvajes, mientras que otros lo hicieron con el combate entre dos galeras y un castillo ${ }^{8}$.

- 1378: En París, en la corte del padre de la novia anterior, el rey de Francia Carlos V, para homenajear al emperador germano, en el salón del banquete se introdujeron, sobre ruedas, la ciudadela de Jerusalem defendida por los sarracenos y un navio lleno de cruzados que la tomaron?.

Este tipo de fiesta gustó tanto en París, que se repitió en otros fastos reales.

- 1399: En Zaragoza, durante el banquete de la coronación del rey Martín el Humano, unos salvajes defienden a una leona (alegoría de la monarquía) contra el ataque de unos bombres armados ${ }^{10}$.

- 1414: En Zaragoza de nuevo, entre los festejos por la coronación del nuevo rey de Aragón, Fernando I, se representó un combate entre dos castillos, simulando la reciente toma de Balaguer por los aragoneses ${ }^{11}$.

A la gran fiesta primaveral religioso-burguesa del Corpus Christi -en la que la sociedad estamental se ofrecía en espectáculo ante sí misma-,

7 Julio CARO BAROJA, Las formas complejas de la vida religiosa (Madrid: Akal, 1978), pp. 419-420, citando un artículo publicado en 1849 por el costumbrista Basilio S. CASTELLANOS, quien indica que leyó el dato en un sermón predicado en 1616 en Zaragoza.

8 Salvador CARRERES, Ensayo de una bibliografía de libros de fiestas celebradas en Valencia y su antiguo reino (Valencia, 1925), pp. 37 y 46.

9 Daniel HeARTZ en Jean JACQuot (ed.), Les fêtes de la Renaissance (Paris: CNRS, 1960), p. 334. Por ésa época, una variante de la danza morisca era bailada por bombres salvajes, como en el luctuoso "bal des ardents" de París en 1393.

10 Manuel MILÁ Y FonTANALS, Orígenes del teatro catalán, Obras Completas (Barcelona, 1895), VI, p. 238: "Nos aproximamos ya a la poesía dramática, sin que por esto puedan llamarse propiamente dramas semejantes espectáculos. Hallamos decoración, personajes, cantos, música y aún hechos representados mímicamente, pero no una acción dialogadan.

11 Ibid., p. 239. 
desde que a principios del s. XIV se instituyeron sus coloristas procesiones callejeras, se le fueron incorporando elementos teatrales para ilustrar las creencias del catolicismo y atraer espectadores. A las figuras inmóviles sobre carros siguieron luego las escenas dialogadas, que desembocarían en los "autos sacramentales" tan característicos del teatro español.

- 1391: En Barcelona, en su procesión del Corpus figuraban, entre otros "entremeses", David y Goliat, que es de suponer representase su bíblico duelo, que hoy día se sigue recordando en numerosas poblaciones ${ }^{12}$.

- 1424: En la misma Barcelona, para festejar el regreso de su rey desde Nápoles, se hizo coincidir su solemne "entrada" con la procesión del Corpus, y por la crónica que lo cuenta se sabe que "la ciudad" contaba con su elenco fijo para la batalla de ángeles y demonios, mientras que los gremios se encargaban de varios "entremeses" bélicos, como el de San Jorge a caballo, la doncella y el dragón; y el de San Sebastián con sus caballitos y el castillo del Gran Turco ${ }^{13}$. También intervenía una danza de "morenos con cascabeles", con lo que ya están presentes casi todos los elementos de las danzas de conquista.

Las procesiones del Corpus de Barcelona y de Valencia, que deslumbraban por su aparatosidad, se convirtieron en modelo a imitar. Pero cuando se trataba de pueblos con escasos recursos, al menos trataban de adornar sus comitivas callejeras con danzas de moros y cristianos, con espadas o palos, y las escenas bíblicas que se pudieran representar.

Apenas se conservan descripciones de los festejos populares ibéricos anteriores al s. XVI, ya que los cronistas trabajaban para la Iglesia y las Coronas, por lo que resulta sumamente valiosa la anónima crónica de Los hechos del Condestable Yranzo a partir de su toma de posesión en 1460 de la plaza fuerte de Jaén, último reducto de Castilla en la frontera con la Granada musulmana. Entre los festejos cíclicos que se realizaban allí, cada 24 de junio, día de San Juan, parte de los caballeros castellanos se disfrazaban de moros, combatiendo en el río contra los que actuaban de cristianos. En el otro solsticio, el invernal, en su palacio se representaba la Historia del Nacimiento de Jesús y los pastores y los Actos de los Reyes Magos con el rey Herodes, apareciendo los tres Reyes Magos a caballo que dialogaban con el malvado Herodes. De carácter totalmente profano, el Martes de Carnestolendas o Carnaval, los hortelanos se proveían de calabazas y se dedicaban a romperlas los unos en la cabeza

12 Fernando LÁzARo CARreter, Teatro Medieval (Madrid: Castalia, 1976, 4. ${ }^{\mathrm{a}}$ ed.), p. 49.

13 Joan AMADES, Las danzas de moros y cristianos (Valencia: Diputación de Valencia, 1966), p. 98 y Milá, op. cit., p. 246. 
de los otros. Y en primavera, por Pascua de Resurrección, los mismos hortelanos de la villa se subían a un castillo de madera que colocaban frente al palacio del Condestable, quien les aguardaba junto con su corte en la torre, pertrechados todos con huevos cocidos, y libraban ambos bandos un grotesco combate durante el que se llegaban a arrojar unos 10.000 huevos. Entre tantos jolgorios, a fines de 1463, durante los días de la fiesta de Navidad y de los Inocentes, para celebrar una reciente y exitosa incursión militar por el reino granadino, "como todos conociesen que el deseo del dicho señor Condestable fuese ejercitarse, después de los hechos tocantes a la guerra, en convites, fiestas y juegos de cañas, y otros actos de placeres honestos, en los que pudiese gastar lo suyo con todos, buscaban invenciones tocantes a esto", y 200 caballeros acordaron disfrazarse, la mitad de moriscos, con barbas postizas, y los otros de cristianos, en lo que llamaron Burlas Moriscas. Consistían en que los moros fingían venir de Marruecos con su rey, encabezados por "su profeta Mahomad, de la casa de Meca, con el Alcorán y libros de su ley, con gran ceremonia, sobre una mula muy adornada" y retaban al Condestable para dirimir en un juego de cañas cuál de sus religiones era la más poderosa: vencieron los cristianos y al estrafalario profeta Mabomad lo arrojaron a una fuente, siendo bautizado luego el falso rey moro. Los parlamentos pronunciados aparecen en la crónica ${ }^{14}$, y son los más antiguos que se conocen de este tipo de fiestas, mientras que bufones similares al irrisorio Mahomad y parecidos retos aún se siguen representando, 544 años después, por la Alpujarra granadina y el estado mexicano de Guerrero.

Muy poco antes, en 1453, el rey francés Felipe el Bueno ofreció en Lille el famoso "Banquete del faisán", con representaciones alegóricas y episodios de la conquista del Toisón de Oro por el héroe griego Jasón ${ }^{15}$. El Renacimiento se imponía por la Europa comercial, y en la propia Roma, la conquista de Granada por los Reyes Católicos en 1492 fue festejada con una corrida de toros, una representación al vivo de la toma y una obra en teatro en latín del secretario papal Velardi, titulada Historia Baetica, que escenifica embajadas, espías, sueños premonitorios, súplicas a la Virgen, liberación de cautivos cristianos y rendición del rey moro. Impresa a los pocos meses de su representación, tuvo bastantes reediciones en España, y debió servir como modelo canónico de teatro épico-religioso.

14 Juan DE MATA CARRIAZo (ed.), Hechos del Condestable Miguel Lucas de Yranzo (Madrid: Espasa-Calpe, 1940), pp. 98-99.

15 M. Lageirse, en J. JaCQUOT (ed.), op. cit. 
El modo de evangelización utilizado con los moriscos de la Granada castellanizada será el que se utilice por los primeros misioneros que desembarcan en el Nuevo Mundo.

En tiempos de los Reyes Católicos, que instauran el ejército permanente y el estado moderno en España, se integran las diversiones de las cortes aragonesas y castellana, siendo aportación de Castilla las danzas habladas, relación romanceada de un suceso a cargo de un músico, mientras que los personajes "con acciones y gestos [...] van ellos significando cuanto el músico canta [...] introducen en sus historias casos y personajes heroicos [constituyendo] la primitiva y ruda comedia castellana" dirá un autor del Siglo de Oro ${ }^{16}$. Pero los espectáculos de mayor repercusión son las simbólicas y estruendosas conquistas de los castillos.

Con el emperador Carlos V llega la influencia de los espectáculos retóricos de Flandes, y las procesiones del Corpus van integrando los alegóricos autos sacramentales. Cuando su vástago Felipe recorra las posesiones paternas por Centroeuropa, en 1549, en la ciudad de Trento, que descansaba entre períodos de sesiones conciliares, fue agasajado con la lucha entre el bando del Infierno, al que pertenecían Hércules y cuatro gigantes salvajes, y el de los hombres armados, y con la conquista de un castillo defendido por turcos y cuatro centauros. La fiesta culminó con el incendio del castillo y de la cueva del Infierno ${ }^{17}$. Meses después, en la belga Binche, en una de las más brillantes fiestas celebradas en Europa, se escenificaron episodios de la novela de caballerías Amadís de Gaula, con la petición de ayuda de la reina encantada para que algún caballero derrotase al Señor del Castillo Tenebroso que la había cautivado. El afortunado que le venció, con la espada milagrosa que conseguía romper el encantamiento fue... el propio Felipe. Días después, los invitados salieron alegremente al asalto del castillo donde unos salvajes se habían llevado raptadas a un grupo de danzarinas ${ }^{18}$. También en los Países Bajos, Brueghel, ese gran pintor que tanto admiraba Felipe de Habsburgo escenificó en 1559 en el Ommegang o desfile cívico de Amberes, la batalla entre Carnaval y Cuaresma, otros famosos bandos antagónicos, que han sido tema de múltiples festejos ${ }^{19}$.

16 Francisco BANCES CANDAMO, Theatro de los theatros de los passados y presentes siglos (Londres: Tamesis Books, 1970), p. 124. Cuenta que él mismo escribió el texto de una danza basada en la ruptura del cerco de Viena por la Santa Liga, que fue representada en Esquivias (Toledo) hacia 1684 y que le divirtió mucho ver a los aldeanos encarnando los personajes de reyes y emperadores.

17 Juan CALVETE DE ESTRELLA, El felicissimo viaje del muy alto y muy poderoso Príncipe D. Phelippe... (Amberes, 1552), ff. 49-52.

18 Daniel Devoto, «iLa famosa fiesta de Bains!», en J. JACQuOT (ed.), op. cit.

19 Sheila Wiluiams, "Les Ommegangs de Anvers et les cortèges du Lord-Maire de Londres", en J. JACQUOT (ed.), op. cit. Ya en el Libro de buen amor del Arcipreste de 
Cuando Felipe II hereda medio mundo, la fiesta que sus cortesanos se esmeran en ofrecerle como espectáculo de su gusto es la conquista de castillos y batallas de galeras, sazonadas con embajadas y desafíos. Esta modalidad festiva se consagra como la fiesta hispánica por excelencia, que une la diversión con la instrucción bélica y el adoctrinamiento político, y a la muerte de este poderoso monarca, en 1598, las representaciones de conquista, especialmente entre los bandos cristiano y musulmán, han arraigado por todos los rincones del vasto imperio español.

Su apoteósis llega en las primeras décadas del s. xvII, cuando los dramaturgos compiten en ingenio para que destaquen sus comedias de Moros y Cristianos, que llegaron a convertirse en un género del teatro del Siglo de Oro ${ }^{20}$. Otra gran aportación fue la de las poderosas órdenes religiosas, que se volcaron en organizar espectaculares demostraciones de alegría por la avalancha de beatificaciones y canonizaciones de sus miembros ilustres con que les dispensaban los Papas. Y el plato fuerte de estos espectáculos callejeros eran las batallas simbólicas. Así, los dominicos de Valencia honraron a su beato Luis Bertrán con el rescate de la dama encantada que unas fieras guardaban en un castillo, escenificándose luego la Toma de Troya ${ }^{21}$. Al año siguiente, 1610, los jesuitas de Granada celebraron la de su fundador con un combate de fuegos artificiales entre dos castillos y las escaramuzas de una compañía de arcabuceros ${ }^{22}$. En 1629 son los mercedarios de Madrid quienes festejaron la santidad de Pedro Nolasco con el fracasado ataque de una galera de herejes al castillo presidido por el santo con la bandera de la Virgen ${ }^{23}$. Finalmente, en 1631,

Hita se cuenta esta alegórica batalla de modo muy plástico y teatralizable. Se sabe que a finales del s. Xv este tema fue representado por Juan del Enzina en la corte de los Duques de Alba, y en 1599 el propio Lope de Vega intervino como botarga (o bufón) en una representación en Valencia de esta batalla en los festejos nupciales del recientemente coronado Felipe III.

20 Estas comedias llegaron a ser tan populares, que Quevedo escribió que "no hay representante que no traiga su farsa de moros y cristianos" en El Buscón, Libro III, cap. 9.

${ }^{21}$ Jenaro ALENDA y MIRA, Relaciones de solemnidades y fiestas públicas de España (Madrid: Rivadeneyra, 1903), I, p. 149. San Luis Bertrán murió en 1581.

22 ANÓNIMO, Relación de la FIESTA que en la beatificación del B.P. Ignacio, fundador de la Compañia de Jesús, bizo su colegio de la ciudad de Granada (Sevilla, 1610). Este mismo año, y por el mismo motivo, su colegio de Cuzco - Perú-, ofreció un festejo que incluía en sucesivos días la batalla entre cañares y canas, con el cautiverio de los segundos; la toma del castillo de los cañares por parte de los incas; y la conquista inca del castillo del mapuche chileno. En la coétanea Relación impresa en Lima en 1610.

23 M. ${ }^{a}$ C. SÁNCHEZ ALONSO, Impresos de los $S$. XV y XVI de temática madrileña (Madrid: CSIC, 1981), p. 173. 
en Cádiz, la beatificación de Juan de Dios fue recibida por sus devotos con un juego de moros y cristianos, fingiendo cautivar la imagen del santo y liberarla luego ${ }^{24}$. Ésta es la primera referencia encontrada al robo del santo como motivo de la confrontación.

Por ésa época alcanzó su última fase evolutiva el fenómeno festivo que estamos rastreando, al irse fijando las normas o moldes que han seguido las actuales representaciones de conquista, ritualizándose al integrarse como componente profano en los actos litúrgicos dedicados anualmente a los santos protectores de cada comunidad, las fiestas patronales o titulares.

Pero la prevención de los clérigos hacia las comedias obligó a que las obras escenificadas por los miembros de las cofradías organizadoras integraran la doctrina religiosa al discurso épico, y sirvieran como exaltación de la fe simultáneamente a la auto-afirmación grupal.

Y para enfatizar lo épico-religioso, se contaba con varios modelos dramáticos de honda raigambre. La mayor densidad simbólica quizás se tenga en el bíblico duelo entre David y Goliat, donde el pastorcillo, con el beneplácito divino, vence al "gigante de hierro" y se casa con la princesa. Emotivamente, los más populares parecen haber sido los cantares de gesta carolingios, con su vibrante reto entre el conde Oliveros y el blasfemo gigante Fierabrás, cuya hermana Floripez se bautiza y desposa al victorioso paladín de Carlomagno. De mayor tradición ritual son los dramas litúrgicos representados en el interior de los templos, con motivo de la Navidad (el Officium Pastorum, con la danza y diálogo de los pastores, a menudo con humor) y la Epifanía (el Misterio de los Reyes Magos, que aparecían a caballo y dialogaban con el rey Herodes ante su castillo). Y en el aspecto argumental, el romancero viejo castellano suministró una variada temática, en gran medida recordando duelos, hazañas y conquistas históricas.

Otra filiación festiva de estos rituales es respecto a las soldadescas, la de las competiciones a las que se entregaban los miembros de las milicias de autodefensa local, en las periódicas reuniones para entrenamiento, revisión de armas y puesta a punto. Felipe II, preocupado por las frecuentes incursiones de navíos berberiscos, había organizado las milicias bajo los cargos jerárquicos de capitán, alférez, sargento y cabo. La revista de las tropas, que ya formalizaran las órdenes militares ${ }^{25} \mathrm{y}$ los musulmanes

24 M. a Soledad Carrasco Urgoiti, "Aspectos folklóricos y literarios de la fiesta de Moros y Cristianos en Españan, PMLA, LXXVIII (1963), p. 485.

25 En el caso de la poderosa Orden de Santiago, la obligación de celebrar los días del Apóstol con variadas "fiestas y ejercicios militares" consta en sus capítulos fundacionales, como recoge Francisco DE OCAMPO, Obligaciones de los cavalleros de la Religión de Santiago, s.l., s.f. (parece que fue escrito a mediados del S. XviI), Const. I, cap. III-10, p. 48. 


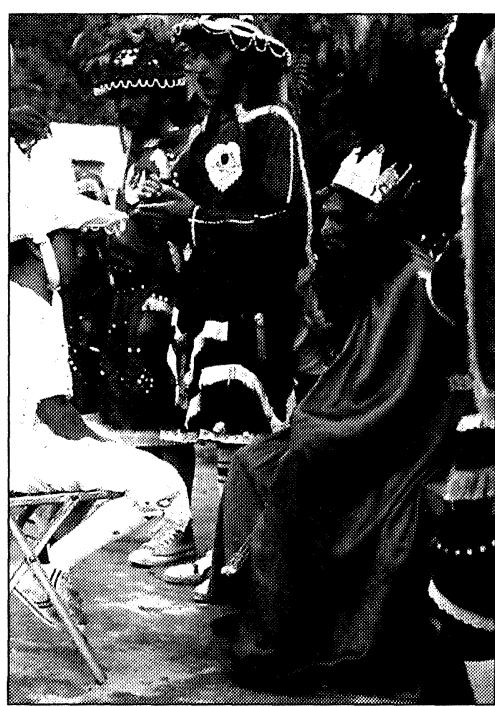

FIG. 7.-El rey moro Pilato platica con el embajador cristiano en la Danza de Moros de Almolonga (Guerrero, México). de Granada, se llamaba alarde, y no dejó de ser practicado por los varones aunque más adelante se disolvieran las milicias, ya que las cofradías y hermandades supervisadas por los clérigos (como es obligatorio desde el concilio de Trento) mantuvieron los mismos cargos - aunque su poder se redujera al simbólico control sobre la fiesta- al ritualizarse sus ejercicios militares. Precisamente, el dato más antiguo que se conoce sobre la representación de moros y cristianos más famosa de España, en la que intervienen miles de personajes, que es la de Alcoy, ilustra este punto: allí, en 1668 festejaban a su patrono San Jorge con una procesión en la que participaban dos compañías:

de Cristianos moros y de Católicos cristianos [que por la tarde hacían] algunos ardides de guerra [y] sujetos a lecciones de milicia se están bélicosamente arcabuceando, encaminándose tanto bullicio en honra, y culto de nuestro santo patrón San Jorge, que en aquellas eras invicto defendió esta Villa, y en la presente la conserva ${ }^{26}$.

En la granadina Béznar, todavía perdura una soldadesca que sigue disparando unos auténticos mosquetes de la época de Felipe II.

Otro emparentado conjunto festivo es el de las competiciones ecuestres, que se pueden remontar a los juegos troyanos de los griegos. Los árabes introdujeron en Hispania el "jerid" o juego de cañas, que se utilizaban como inofensivas lanzas, donde se enfrentaban dos o cuatro cuadrillas de jinetes que trataban de capturar a sus enemigos. Estos juegos, que acreditaban la pericia en el arte de cabalgar, solían iniciarse con desafíos mutuos, y desde el s. Xv se extendieron por los reinos cristianos en sustitución de los torneos, a menudo disfrazándose un bando con ropa morisca. En la variante de los norteafricanos bereberes de este juego, la maya, ambos bandos se disputan un pelele vestido como mujer ${ }^{27}$.

26 Juan Berenguer, Historia de los Moros y Cristianos de Alcoy (Alcoy, 1974), p. 71.

27 Fernando Álvarez, "Usos y costumbres de Marruecos", África, núm. 10 (octubre 1942), pp. 21-22. 
Finalmente, aún queda otro universo festivo conectado, el carnavalesco, que se impone en algunos aspectos de los actuales rituales de conquista. Así, el despliegue de vestimenta, asimilable a los disfraces, que se ha convertido en uno de los distintivos de los alardes valencianos de Moros y Cristianos, con sus abigarradas comparsas con sus bandas de música y su sensual ritmo dancístico de desfilar. En los dances aragoneses y los dichos conquenses se incluyen las mojigangas o sátiras sociales; e incluso en las adustas relaciones granadinas, escenas y personajes de matiz bufonesco desahogan al público de la seriedad de los parlamentos. En Galicia todavía perduran las carnavalescas guerras o encuentro de los generales, con burlescos retos entre los jefes de las militarizadas comparsas de aldeas vecinas. Similares mascaradas territoriales se efectúan en el Norte de la Península durante el Carnaval, incluyendo entre sus elementos al oso cautivado. Más adelante volveremos sobre este universo ritual.

Como colofón a este recorrido diacrónico, propongo un mapa-modelo de formas festivas, que presenta las zonas peninsulares en las que predominan algunas las que se han ido estudiando, así como las posibles influencias procedentes del exterior de la Península.

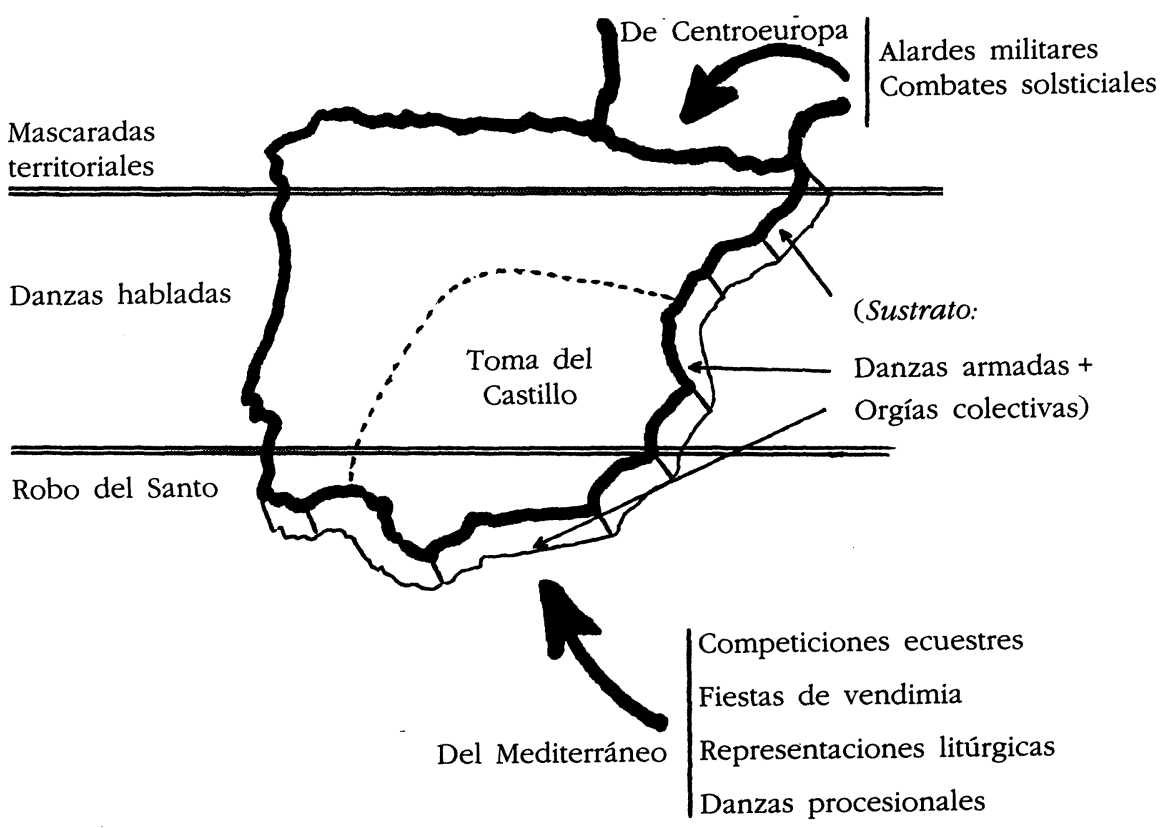

GRÁfico 2.-Mapa-modelo de formas festivas en la Península Ibérica. 
DEMETRIO BRISSET

\section{RITUALES ASOCIADOS}

Como última etapa en la recogida de elementos significativos sobre este complejo simbólico global, vamos a examinar otros rituales que aparecen actualmente asociados con los de conquista, compartiendo la misma estructura festiva y formando parte ambos del mismo contexto ritual:

1) Colectas o rescates: Abundante documentación judicial demuestra la importante misión que cumplían estas representaciones para recaudar las limosnas con las que sufragar el culto y las actividades de las cofradías, y la oposición continua de las autoridades - que consideraban inútiles los gastos en pólvora, comida y bebida - respecto a los fieles, para quienes la limosna y los actos profanos eran inseparables. Entre las modalidades de recolectar los donativos, hay significativos casos en los que se efectuaban como rescates conectados con la representación, ya que los vecinos debían "comprar" u obtener la liberación de la imagen del santo, de algunos personajes cristianos o la suya propia, al ser apresados por los miembros del bando moro. Esta última acción es asimilable a la que efectúan las autoridades burlescas de la fiesta de los Inocentes, que tienen la prerrogativa de encerrar en la cárcel a cualquiera que no contribuya al culto de "las ánimas benditas".

2) Ofrendas: Este símbolo de la obligación o compromiso comunitario hacia el representante local de la esfera sagrada, normalmente se conduce procesionalmente hasta el templo por las doncellas o "mozas". Entre las ofrendas vinculadas a representaciones de conquista sobresalen: frutos, "pan bendito", "ramos" o adornadas roscas de manteca y animales vivos (toros y carneros).

3) Culto funerario: En algunos sitios se visitan los cementerios, llegando a disparar los arcabuces y escopetas al pie de las tumbas de los difuntos familiares, y en otros se celebran misas en sufragio de los fallecidos miembros de cada bando.

4) Danzas: En una gran zona, la procesión con la imagen del patrono es acompañada por una danza ambulatoria, y al llegar a la plaza se detiene para que los danzantes ejecuten sus paloteos y/o danza de espadas, colocándose en dos filas enfrentadas para encarnar, sin diferencia de ropaje, los bandos antagónicos y desarrollar la acción teatral. A su término, se ejecutan nuevas mudanzas. Aquí, la representación de conquista es un eslabón más de la danza en sí, que se presenta como danza hablada.

5) Bebedizos embriagadores: Es abrumadora la continua hostilidad de las autoridades civiles y religiosas hacia la embriaguez colectiva que se alcanzaba en el transcurso de estas representaciones. Los accidentes ocasio- 
nados al perder el control sobre el manejo de la pólvora, especialmente en las rebosantes de disparos y tracas fiestas valencianas y granadinas, propiciaron la prohibición de las soldadescas de moros y cristianos en tiempos de la Ilustración, y casi las hicieron desaparecer.

6) Las enigmáticas colmenas: En varias representaciones se encuentran asociadas las colmenas, bien como uno de los objetos en disputa (figurando servir como cañones) bien en pantomimas respecto a su castración, con claras alusiones eróticas. Se las puede entroncar con los cultos a la fertilidad que en la Antigüedad romana se dedicaban en primavera a la diosa Ceres.

7) Sátiras comunitarias: A veces coexisten rituales de conquista con la mojiganga o burla de los sucesos locales en el año transcurrido desde la última fiesta, especie de expiación catártica por la auto-culpabilidad comunitaria. Cualquiera de los actores puede encargarse del cometido, aunque los que hacen de bufones suelen ser los más apropiados para el papel, en una acción semejante a los satíricos y carnavalescos testamentos del burro, la zorra, la sardina o el guirria.

\section{LAS RAÍCES CARNAVALESCAS}

El punto anterior nos vuelve a introducir en otro universo festivo ritual, el carnavalesco o de las mascaradas invernales, que ya se mencionó, y lo considero de tal importancia en la gestación de las representaciones de conquista, que merece que se le dedique un apartado propio.

En varios momentos se ha ido viendo la estrecha conexión entre ambos conjuntos festivos, en lo tocante a los disfraces, personajes bufonescos, las batallas de huevos cocidos, las mojigangas o sátiras comunitarias, hasta llegar incluso a casos en los que se celebra la representación de conquista en el mismo Martes de Carnaval ${ }^{28}$. También se pueden trazar paralelismos rituales que poseen un enigmático sentido.

Así, la cadena secuencial dramática Captura-Juicio-Muerte, que tiene lugar en ciertas danzas de conquista, es equivalente a la que sucede con los peleles o fantoches que simbolizan al Carnaval en buen número de localidades, que tras un efímero "reinado" terminan siendo pasto de las llamas o de la pólvora. Y en íntimo parentesco, tenemos un tradicional personaje ritual que nos puede dar una pista clave para la descodificación.

${ }_{28}$ Como en las orensanas Carballal y Larouco, mientras que en la granadina Vélez de Benaudalla se sabe que su representación de Moros y Cristianos a fines del S. XviII se celebraba durante las Carnestolendas, acompañada por la corrida de los toros que invernaban por los pastos del término, que luego se iban a capar o castrar, para quebrarles así la fuerza. 
En muchas mascaradas invernales europeas, desde los Pirineos a los Cárpatos pasando por los Alpes, todavía conserva su protagonismo el personaje del oso. Habitualmente forma pareja con el domador, quien tiene problemas para sujetarlo e impedir que se lance contra las mujeres, y suele terminar matándolo... para que el oso resucite. La forma más elaborada de esta representación ritual se mantiene en los Pirineos franceses hacia la época en la que el invierno inicia su declive: surge del bosque un oso que intenta raptar una de las mujeres del pueblo: Después de intensa lucha, el grupo de cazadores consigue encadenarlo y lo lleva a la plaza donde pierde simbólicamente su salvajismo al ser rasurado por un barbero, "resucitando" como ser humano civilizado ${ }^{29}$. Otra significativa cacería del oso es la que se ha recuperado en comarcas de la Cordillera Cantábrica española (morada de la mayoría de los osos pardos europeos), donde la mascarada carnavalesca se compone de un bando blanco y otro negro que luchan entre sí, para terminar unidos en la caza, juicio y muerte del oso.

En lo que respecta a representaciones más elaboradas, un tema extendido por las cortes medievales europeas fue el del simulado combate entre hombres armados o civilizados y otros salvajes. Así, en la italiana Padua, consta que en Pentecostés de 1208 tuvo lugar un gran juego del hombre salvaje, lo que constituye "una de las primeras referencias de actividades teatrales en ese país desde la desaparición del teatro romanon. Otra remota referencia se tiene en 1399 , en la Suiza "que ha conservado algunos cultos del hombre salvaje hasta el presente, actuando como protector de los rebaños de las altas montañas durante los veranos" ${ }^{30}$. Ya se vió que en 1373, en España, un grupo de hombres salvajes atacó a la comitiva de la novia real para servirle como diversión. Y a partir de entonces son muy abundantes las noticias de su participación festiva.

Todavía en nuestro siglo se siguió representando la caza del hombre salvaje en Austria, el Tirol, los Alpes italianos, Turingia y Checoslovaquia, con un ritual muy semejante: lo encuentran en su cueva o en el bosque, es un ser atemorizante, los cazadores le persiguen hasta capturarlo y encadenarlo, para ser luego expulsado del lugar o fusilado, terminando a

29 Arnold VAN GENNEP, Manuel de folklore français contemporain (Paris: A. et J. Picard, 1947) t. $1 .^{\circ}$, III, pp. 908-909. La doncella, llamada Rosetta, es un hombre disfrazado, que es cautivada por el oso en una especie de cueva-cabaña, levantada sobre la plaza. Después de capturado y muerto, el oso resucita. Dice este eminente autor que: "Sin pretender que este argumento sea una supervivencia prehistórica, hay que reconocer que está constituído por elementos muy primitivos y que debían haber sido más brutales, y también más eróticos".

30 Richard BERNHEIMER, Wild men in Middle Ages (Cambridge: Harvard Univ. Press, 1952), pp. 51-52. 
veces paseado en su ataúd o arrojado a un pozo (encarnado en un pelele). Y a veces se celebra su juicio:

Entre las variantes de esta cacería están aquellas en las que la criatura pierde su nombre y se convierte en oso: transformación fácilmente ejecutable considerando que el oso —el "hombre de los bosques" - puede sostenerse de pie como un humano, y que además el hombre salvaje con su vestido de pieles se le parece. En estos rituales, la distinción entre hombre y bestia no es siempre rigurosamente conservada [y] hay lugares en los que incluso no se reconoce esta distinción. En Eger (Checoslovaquia) se refieren a su rito anual, que es la caza de un hombre salvaje, como la matanza del oso, y en Hesse (Alemania) la criatura se llama sinónimamente "el hombre salvaje" $\mathrm{O}$ "el oso salvaje" ${ }^{31}$.

"Para el prof. Rhys Carpenter, la equivalencia entre oso y bombre salvaje es muy antigua, y el oso puede posiblemente ser la figura anterior. Un rastro de esta conexión está en la equivalencia lingüística entre 'orcus' (hombre salvaje) y 'ursus' (oso)" ${ }^{32}$. En cuanto a España, el topónimo ibérico "arco" está conectado con "Oso", lo que también demuestra la existencia aquí de un culto al oso ${ }^{33}$.

Más adelante volveremos a estos personajes, pero ahora examinemos unos singulares rituales de fin de año que se siguen efectuando en el norte de España. Bajo los nombres de encontros, cortejos, vijaneras y zamarronadas, en muchas aldeas se forman bandos de hombres jóvenes que se colocan tradicionales disfraces, entre los que no suelen faltar los del oso y su domador, y en ruidoso cortejo visitan los pueblos cercanos para representar sus pantomimas y bailar, recolectando víveres para el posterior banquete. Las relaciones entre las diversas mascaradas locales son frágiles, pudiendo llegarse a enfrentamientos abiertos. Este hecho parece reflejar que tales simbólicas confrontaciones rituales subliman conflictos de territorialidad entre comunidades limítrofes. En el ya mencionado caso de los encontros de Galicia, cada bando está al mando de un general a caballo, que a las puertas de cada pueblo en su itinerario envía un embajador o correo para preguntar si se les permite entrar, y si les es concedido, a la entrada del pueblo se entabla un ingenioso diálogo entre ambos generales, con burlescos desafíos. La conexión con las representaciones de conquista es evidente.

31 Ibid., pp. 53-54.

32 Ibid., p. 198.

33 ¿En la Península está atestiguado, de manera semejante a lo que ocurre entre las poblaciones indoeuropeas de fuera de ella, el culto al oso; así se deduce del topónimo Arcon, en José M. ${ }^{a}$ BLÁZQUEZ, Diccionario de las religiones prerromanas en Hispania (Madrid: Istmo, 1975), p. 21. 
Otro significativo ritual se tiene en la sierra de Zamora, donde en carnavales se representaba el ataque de unos diablos a una pareja de novios, raptando y matando a su bijo. Salían a luchar contra ellos una banda de soldados, que les vencían y cautivaban, unciéndoles a un yugo con un arado y obligándoles a arar las calles como si estuviesen sembrando cereales. Aquí, la conexión directa con el culto a la fertilidad es muy reveladora. Y la fechoría de los diablos es similar al acto central de un ritual dionisíaco que pronto se verá.

\section{LOS SIMBOLOS SUPERPUESTOS}

Creo que ha llegado el momento de ahondar en el complejo simbólico constituído por las luchas rituales en el resto del mundo. Es sabido que uno de los actos rituales de las fiestas de Año Nuevo en Mesopotamia era el recitado público del Enuma elis o "Poema de la Creación" (compuesto antes del s. xvir a.C.), que evoca el épico duelo entre el creador de la humanidad, Marduk, y el principio femenino u océano, Tiamat. Por medio de embajadas se establece una alianza entre los dioses favorables a Marduk, y éste reta a su enemiga, prosiguiendo con una serie de acciones dramáticas que incluyen muertes y cautiverios, lo que recuerda muchos episodios de nuestras actuales representaciones de conquista. Aquí, el objeto de la batalla es la posesión de las tablas del destino, símbolo de la potestad de dictar el futuro y, por tanto, regir la vida de la naturaleza y de los humanos ${ }^{34}$.

En otro antiquísimo ámbito cultural, la India, todavía se siguen representando en las bodas trozos del Ramayana, con la persecución y combate del héroe Rama contra los demonios, que le han raptado a su novia Sita.

La etnografía mundial documenta variados ceremoniales de confrontación, entre los que me limito a señalar:

$\begin{array}{ccr}\text { Localización } & \text { Bandos enfrentados } & \begin{array}{r}\text { Motivo del ritual } \\ \text { Suecia, Baviera, }\end{array} \\ \text { isla de Man. } & \text { Verano - Invierno } & \text { Llegada del buen tiempo } \\ \text { Canadá } & \text { Nacidos en verano-en invierno } & \text { Prolongar el buen tiempo } \\ \text { Andes Perú } & \text { Aguas - Secas } & \text { Saber qué tiempo hará } \\ \text { Birmania } & \text { Lluvia - Sequía } & \text { Tener lluvias } \\ \text { India } & \text { Mujeres - Hombres } & \text { Tener buena cosecha } \\ " & \text { Un bando en cada ribera del río } & \text { Expulsión de plagas } \\ " & \text { Espíritus buenos - malos } & \text { Funeral }\end{array}$

34 ANÓNIMO, Poema babilónico de la Creación (Madrid: Edit. Nacional, 1981), tablilla IV. 
Australia

Alto Nilo

México ${ }^{35}$
Vecinos - Hombres de ceniza

del dios-del rey que lo encarna de la diosa-autoridades
Expulsión almas difuntos Proclamación monarca Aplacar terremotos

Como se puede apreciar, los motivos explícitos de estos rituales de confrontación pueden ser naturalistas, funerarios y de identificación de reyes con divinidades. A ellos tendríamos que añadir tantísimas luchas de iniciación de los jóvenes guerreros. Por otra parte, los ritos agónicos (del agon o enfrentamiento ritual entre dos bandos que constituyó el núcleo del teatro clásico griego) tuvieron en los misterios dionisíacos uno de sus mejores exponentes, en la lucha entre curetes y titanes por el niño Dionisio, que los primeros despedazaban.

Regresando a esta investigación, intentaré buscar una interpretación de los rituales estudiados. Para ello, puede ser útil recordar las opiniones que al respecto han expresado algunos de los investigadores que se han ocupado del tema.

Hay que notar en primer lugar un hecho sorprendente: no se han establecido polémicas ni apenas referencias a las teorías ajenas ${ }^{36}$. Son muchos los autores que siguen a Ricard y a Warman, sin llegar a replantear sus posiciones. La explicación podría ser tanto el general desconocimiento mutuo de las investigaciones realizadas en ámbitos distintos, como por la dificultad inherente al objeto de estudio de arriesgar teorías e interpretaciones sobre un complejo cultural tan vasto y difuso. Una vez sentada esta premisa, comencemos por repasar las opiniones. Que yo sepa, ningún autor español ha investigado en profundidad las representaciones de Moros y Cristianos en España en conexión con las de otras danzas de conquista ni con las que se hacen en otros países ${ }^{37}$. En este aspecto, el mérito de ser el primero en comparar las representaciones de ambos lados del Atlántico recae en R. Ricard (1932), para quien "no hay diversión popular que atestigüe mejor que las llamadas fiestas de Moros $y$ Cristianos la unidad fundamental de la cultura hispánica", opinando que fueron "diversiones urbanas, aristocráticas y cortesanas, antes de terminar,

35 En la fiesta prehispánica de septiembre en honor ade la diosa llamada Toçi, madre de los dioses y corazón de la tierra [...] hacían una fingida escaramuza y combate», en Fray Diego DuRán, Ritos y fiestas de los antiguos mexicanos (escrito entre 1576-78), (México D. F.: Ed. Innovación, 1980), cap. XCIII, p. 189.

36 Salvo en el caso de "la segunda generación aragonesa" (A. Beltrán y M. Pueyo), que rebate ciertas afirmaciones de sus predecesores en el estudio del dance ( $\mathrm{R}$. del Arco y A. de Larrea), no he encontrado ningún contraste de opiniones.

37 Recientemente han aportado interesantes sugerencias los antropólogos Manuel Gutiérrez (Madrid) y Pedro Gómez (Granada). 
con posterioridad, siendo recreaciones populares y campesinas" ${ }^{38}$. Este juicio puede ser cierto en lo tocante a su última envoltura formal, pero que se ejerce sobre unos rituales populares preexistentes, como se verá luego.

El siguiente investigador que estudia diacrónicamente estos rituales tanto en España como en México es A. Warman (1972), quien considera las danzas de moros y cristianos como "uno de los símbolos de la España imperial, unificada y en proceso de expansión" ${ }^{39}$. La que era una diversión de gente armada es llevada a América, que se ve como una nueva "cruzada cristiana": "llega como resultado de un proceso de selección y síntesis de elementos de la cultura española [...] la existencia de antecedentes prehispánicos [motiva que vuelva a ser seleccionada] como una extensión de la cultura de conquista" ${ }^{40}$, pero si ha persistido es "por su función, y no por su forma" ${ }^{41}$, asociada al sistema de cargos indígenas. En su propuesta de ampliación de la hipótesis a la propia España, creo que también se debe tener en cuenta el otro importante factor del contenido carnavalesco que la hizo más aceptable para los sometidos campesinos.

Un año antes, comparando esta vez varias representaciones de México, Guatemala y los Andes, N. Wachtel había demostrado la unidad estructural existente entre sus respectivos argumentos. Respecto a su significado actual, con la variante quiché como ejemplo dice que: "Hoy día el mensaje explícito de la obra puede no ser percibido como tal. Los indios actuales lo interpretan más como homenaje a la heroica resistencia de Tecum que como glorificación del cristianismo y de Alvarado" ${ }^{42}$. Lo mismo se puede decir de muchas de las representaciones españolas, en las que el mensaje religioso ha quedado diluído para que afloren otros significados anteriores. Finalmente, y de nuevo a partir de un estudio sobre un caso mexicano, G. Beutler (1984) afirma que "las Fiestas de moros y cristianos sobre todo son una estructura, una sucesión de ciertos movimientos (desafíos, batalla, victoria) con la significación de una victoria del bien sobre el mal", entroncando estas danzas con las de espadas ${ }^{43}$.

38 Robert RICARD, "Contribution a l'etude des Fêtes de Moros y Cristianos au Mexique", Journal de la Societé des Americanistes, XXIV (1932), p. 872.

39 Arturo WARMAN GRYJ, La danza de moros y cristianos (México D. F.: INAH, 1985, $2 .^{a}$ ed.), p. 23.

40 Ibid., p. 141.

41 Ibid., p. 52.

42 Nathan WACHTEL, Los vencidos (Madrid: Alianza, 1976), p. 79.

43 Gisela BEUTLER: La bistoria de Fernando y Alamar (Stuttgart: F. S. Verlag Wiesbaden, 1984), p. 175. 
Antes de adentrarnos en la problemática de la significación de estas danzas-teatro, bueno será escuchar a varios de los investigadores del fenómeno dentro del ámbito del territorio español.

La primera aportación es la del casi desconocido E. Arqués (1953), quien en una etnografía sobre los moros de Marruecos refiere de pasada las fiestas populares españolas de Moros y Cristianos, en las que percibe:

una imagen desfigurada, "des-historiada" de lo que fue la lucha de la vida rural contra las fuerzas rivales de la naturaleza: el desamparo del pastor y labriego frente a los rigores del invierno, tempestades y nieves, y el cerco terrible de las fieras. Esto tiene, a pesar de su transformación en leyenda épica, el significado cabal de lo que representa la lucha de Jorge y el dragón, de Marduk y Tiamat [...] Todo en un puro simbolismo de la contienda y la victoria de la primavera sobre el invierno ${ }^{44}$.

Esta es una interpretación intuitiva del autor, que me propongo demostrar.

Le sigue G. Guastavino (1969), quien propone un método sistemático para el estudio total de nuestro tema. Tratando sobre la posible influencia de las fiestas cultas sobre las populares, piensa que "son dos procesos que se desarrollan en forma paralela: uno a nivel cortesano y otro a nivel popular ${ }^{45}$. Respecto a su origen, considera que se debe buscar en las antiquísimas danzas paganas, que củando tienen como núcleo la lucha "no creo que quepa duda de que en el sustrato de las mismas yace la eterna pugna entre el Bien y el Mal, tanto sea la lucha contra las fuerzas malignas de las calamidades, de los elementos o de las enfermedades, como sea una lucha más concreta contra unos enemigos humanos" ${ }^{46}$.

La hipótesis de la confrontación Bien-Mal es retomada por M. ${ }^{a} \mathrm{~S}$. Carrasco (1976), quien además encuentra un vínculo entre la quema de las Mahomas en varias fiestas de Moros y Cristianos valencianas con la de los Judas, considerándolas "más bien un símbolo maligno comparable al Rey del Carnaval [cuya destrucción] ahuyenta los futuros males" ${ }^{47}$. Por último, el maestro J. Caro Baroja en sucesivas aproximaciones al tema, relaciona las danzas de moros y cristianos, ejecutadas por comparsas de hombres armados en el solsticio de verano, con las de espadas:

44 Enrique ARQUÉs, Tierra de moros, estampas de folklore (Tetuán: Instit. Gral. Franco, 1953), p. 74.

45 Guillermo Guastavino, op. cit., nota 2, p. 17.

$46 \quad$ Ibid., p. 13.

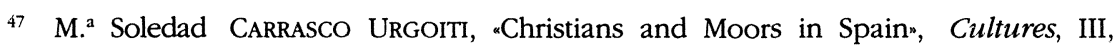
núm. 1, (1976), p. 109. 
antiquísimas en toda Europa [por lo que su origen es] en parte anterior al medieval que comúnmente se les atribuye [y] los detalles que parecen como inspirados en el mayor espíritu histórico, por ejemplo, la lucha del rey moro con el rey cristiano, pueden suponerse relacionadas con otros tipos de pugnas como la de fingir las luchas de invierno y primavera, la vida y la muerte, etc., por dos bandos ${ }^{48}$.

Analizando la simbología del personaje del moro de la danza, halla una asociación con el "mal", concluyendo que "en cada época el Bien y el Mal han tenido que ser representados por personajes distintos" ${ }^{49}$.

\section{Propuesta interpretativa}

Resumiendo lo hasta ahora escrito, creo que las actuales danzas de conquista fortalecen la auto-afirmación comunitaria al presentar una visión heroica de su pasado que, si bien pretende ser histórica, sus oscilantes dosis de anacronismo e idealización orientan hacia lo mítico, y que a pesar de su amplio espectro argumental poseen la misma estructura semántica. Es destacable su expresión formal como juego de rivalidad a cargo de los varones adultos, que indistintamente forman parte de cualquiera de los bandos enfrentados, donde las mujeres hasta hace muy poco ni siquiera participaban. Cumplen la función de rito iniciático para los nuevos "hombres de armas" y la de prestigiar a sus organizadores e intérpretes, así como las restantes funciones sociales que ejercen las fiestas patronales o titulares en la cultura hispánica.

En estas representaciones rituales masculinas se actualiza una situación simbólica en la que, simultáneamente y en orden decreciente de superficialidad, se trasmiten los siguientes mensajes:

1) Hay una religión verdadera, la católica. Los modelos textuales fueron escritos por clérigos, con el énfasis puesto en el plano apologético y el valor de las creencias, demostrando la verdad de su fe por la victoria rememorada. Vence el bando del dios más fuerte, aunque pueda venerarse mediante una mezcla sincrética de cultos.

2) Hay un orden jerárquico, que se reproduce simétrico en ambos bandos. Se legitima la autoridad, con los reyes y el castillo como símbolos políticos. Es la única estructura social permisible.

3) Hay un territorio propio, que se defiende. El patriotismo se presenta como valor normativo, y el sentido de la independencia local se manifiesta con las milicias o bandos militares aptos para la autodefensa

48 Julio Caro Baroja, La estación de amor (Madrid: Taurus, 1979), pp. 262 y 273.

49 Julio Caro Baroja, El estío festivo (Madrid: Taurus, 1984), p. 130. 
comunitaria, lo que reafirma la voluntad de permanencia en las tradiciones propias. La confrontación simbólica también refuerza la integración social, al liberarse las tensiones auto-destructivas.

4) Se reactualiza una fechoría. Los enemigos tratan de raptar o apoderarse de un bien colectivo. El metasímbolo de los "objetos de la batalla" creo que es la imagen del representante local de la divinidad, el protector contra los males públicos y privados, que reasegura su patrocinio al volver a vencer a los enemigos rituales, aunque pueda ser cautivado inicialmente.

Si nos centramos en la clase actualmente hegemónica, el Combate de Moros y Cristianos, la minicadena narrativa constituída por el cautiverio rescate ${ }^{50}$ se puede asociar semánticamente con otra secuencia de dos acciones opuestas como es la del ocultamiento-hallazgo, que configuró un ciclo temático muy extendido durante el Siglo de Oro, inspirado en el descubrimiento por los cristianos, cuando recuperaban el dominio territorial, de cuerpos de santos o imágenes ocultadas por los hispano-godos a la llegada de los invasores árabes. Los escondidos símbolos sagrados eran sacados a la luz, a la superficie. Y la diada de acciones se puede expresar como enterrar-desenterrar, que puede servir como metáfora del par muerte-resurrección. Aquí, el primer término ha generado el ritual de expulsión de las ánimas de los difuntos, mientras que su antagónico ha dado pie a las religiones, que brindan un poder mágico sobre la muerte.

Fijémonos ahora con detalle en los enemigos rituales. En el subconjunto Moros y Cristianos no se establecen distinciones dentro del bando moro o musulmán entre árabes, marroquíes, nazaríes, moriscos, turcos y berberiscos, seculares enemigos de los castellano-aragoneses. De hecho, en situaciones de confrontación intercultural e interétnica como las de los siglos XVI y XVII en todo el imperio español, los enemigos rituales servían como contra-modelo para cimentar la cohesión sociocultural y las señas de identidad colectiva. Pero en la memoria popular también se designa como moros a los antepasados, esos seres míticos que perduran encantados guardando los tesoros ocultos bajo tierra, emparentados con divinidades ctónicas y civilizadoras.

Respecto al subconjunto americano de las Danzas de Conquista, se establece cierta dualidad heroica, ya que se han heredado la religión del bando invasor y las tradiciones del vencido, pero ahora mismo son las propias

50 Históricamente parece reflejar lo sucedido en 1254 con el rey San Luis de Francia en la VI Cruzada, liberado de su cautiverio por los musulmanes tras el pago de un cuantioso rescate, sabiendo que este monarca fue luego presentado como "modelo de vida" para la Cristiandad medieval. 


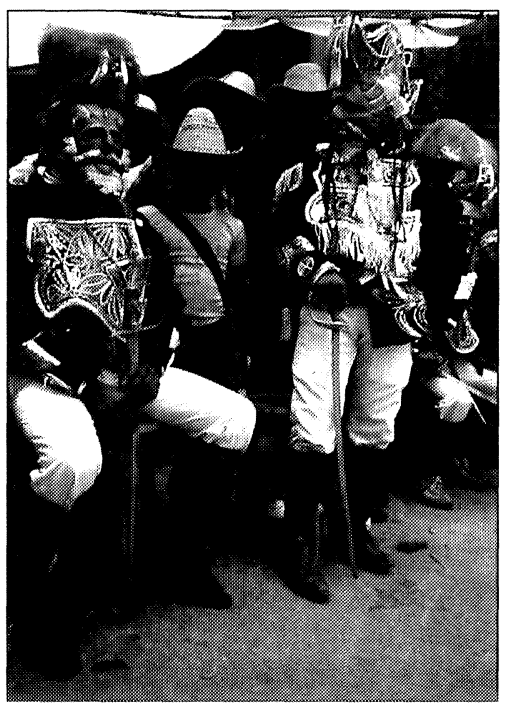

FIG. 8.-Un terrible D. Pedro de Alvarado encabeza el bando español en el Baile de la Conquista de Joyabac (El Quiché, Guatemala). comunidades las que controlan su ritual festivo y reivindican con orgullo su cultura indígena. Los españoles ya no son enemigos, puesto que fueron expulsados (aunque sus herederos criollos siguen dominando), pero su dios demostró ser más fuerte, y se le tiene ahora por protector, sin que por ello se olviden las formas de culto de las antiguas religiones locales.

Ahora bien, considero que hay otros subconjuntos de Danzas de Conquista que constituyen estadios anteriores del mismo complejo simbólico, que en su gran mayoría han persistido al ampararse en los rituales carnavalescos.

El hecho de que las luchas rituales contra los osos se extiendan también por Siberia y el norte de América y de Áfri$\mathrm{ca}^{51}$ denota su gran fuerza simbólica. Y por los huesos de osos de las cavernas hallados en asentamientos paleolíticos, se vislumbra un posible culto a este plantígrado depredador con el que nuestros antepasados tenían que competir para disfrutar del refugio ${ }^{52}$. Pero el ursus no era sólo una fiera atemorizante, sino que se le asociaba con el invierno, época en la que permanece aletargado, y su derrota corresponde a la del mal tiempo; es vencido cíclicamente por la luz, el calor y las flores de la primavera. En cuanto a la antigüedad de su inclusión en un ritual festivo, se sabe que el franco Hinamar de Reims, en el s. IX, encontró necesario atacar lo que él llamaba turpia ioca cum urso, reprensibles juegos en los que intervenían osos, mujeres danzantes y máscaras demoníacas "como parte de un programa total, lo que no deja duda del carácter ritual de la representación que ataca. De hecho, puede haber sido muy similar a la que todavía se practica en los Pirineos" ${ }^{53}$. Respecto a España, la referencia más antigua a una fiesta del oso se ha encontrado en 1444 en Cataluña ${ }^{54}$.

51 Datos suministrados por James G. Frazer, La rama dorada (México D. F.: Fondo de Cultura Económica, 1981, 9. ${ }^{a}$ ed.), caps. LII y LIII.

52 André LeROI-GOURHAN, Les religions de la prebistoire (Paris: P.U.F., 1983): "La discusión está todavía abierta y lo seguirá por mucho tiempon (p. 32).

53 R. BERnHEIMER, op. cit., p. 55: “Un siglo después, Regino de Prüm repite esta prohibición".

54 A. VAN GENNEP, op. cit., p. 910. 
En cuanto al simbolismo de ese personaje conectado con el del oso, el hombre salvaje, para el medievalista Bernheimer refleja la capacidad de ejercer fuerzas que su hermano civilizado ha reprimido en su lucha por autocontrolarse. En contraste con el hombre civilizado, es un hijo de la naturaleza de la que depende, representa las fuerzas elementales que existen dentro de nosotros pero que son ahogadas por las restricciones sociales. El terror que inspira se exorciza como burla, lo formidable se vuelve grotesco. Considera que se le debe relacionar con los locos y marginados sociales, con lo extraño, lo inculto, lo ingobernable y lo ininteligible; es un vehículo de expresión del repudio al hierático orden de la sociedad medieval, y focaliza varios instintos y deseos humanos, como muestra la grosera lascivia con la que se lanza contra las mujeres. En su combate contra el caballero por la posesión de la dama, encuentra implicaciones mitológicas del rapto que lleva al humano al otro mundo. Por los temas de romances, leyendas épicas, cuentos, baladas y la iconografía medieval, lo considera representante del demonio de la muerte, y su apogeo lo sitúa a finales de la Edad Media, cuando crecía la influencia burguesa y el poder de los núcleos urbanos ${ }^{55}$.

Para ubicar a estos personajes salvajes dentro del contexto histórico de los carnavales, podemos seguir a Heers en su investigación sobre las medievales fiestas de los locos, donde admite una doble influencia entre las fiestas oficiales y las populares: los ritos populares son utilizados para la creación de grandes espectáculos, que a su vez sirven luego como modelos que se imitan en los pueblos pequeños.

Así, en esquema ${ }^{56}$ :

JUEGOS BURLESCOS $\left\{\begin{array}{l}\text { En las entradas reales, cortejos-espectáculos y las } \\ \text { mascaradas, intervienen bombres y mujeres sal- } \\ \text { vajes, a los que se añaden dragones y gigantes. }\end{array}\right.$

Parodias de juicios burlescos (a cargo de las alegres sociedades profanas, desde el s. XIv)

Se incorporan a los cortejos de carnaval, junto con farsas con temas de mitos épicos y asaltos de locos a castillos de la moral, donde se han refugiado las virtudes, personificadas por doncellas cautivas.

55 Ibid., pp. 3, 121-125 y 145.

56 Jacques HEERs, Fêtes des fous et carnavals (Paris: Fayard, 1983), extractando las pp. 159, 237 y 261. 
Por otro lado, Bajtin propuso esclarecedoras ideas sobre la carnavalización de las fiestas populares europeas. Para este autor, la cultura oficial religiosa y feudal de los siglos VII y VIII, e incluso IX, era aún débil y no se había formado completamente, mientras que la cultura popular era muy poderosa y había que tenerla en cuenta, por lo que se utilizaron algunos de sus elementos con fines propagandísticos. Como seguían vivas las tradiciones cómicas populares de la época del imperio romano, la Iglesia "hacía coincidir las fiestas cristianas con las paganas locales relacionadas con los cultos cómicos, con el propósito de cristianizarlas" ${ }^{57}$, pero las restricciones en contra de esta tolerancia se intensificaron. De modo paralelo, personajes de la tradición carnavalesca pasaban de las plazas públicas a los regocijos de las cortes (mascaradas, procesiones, alegorías) donde se transformaba su estilo e interpretación. A partir de mediados del s. XVII, se produjo un generalizado empobrecimiento de los ritos y espectáculos populares, y:

al desaparecer y degenerar las diferentes formas de la fiesta popular legaron al carnaval algunos de sus elementos: ritos, atributos, efigies y máscaras. De este modo, el carnaval se convirtió en el depósito adonde iban a parar las formas que habían dejado de tener existencia propia [por lo que el carnaval] representa el elemento más antiguo de la fiesta popular ${ }^{58}$.

Una interesante aportación teórica de Bajtin para entender los mecanismos de trasmisión ritual de los símbolos es el concepto de sistema de imágenes de la fiesta popular, que según él "se formó y existió durante milenios [enriqueciéndose] con un sentido nuevo al absorber las nuevas experiencias e ideas populares", aportando tal sistema de imágenes "derechos de libertad y de licencia, reconocidos y consagrados por los siglos" ${ }^{59}$. Así, en los rituales carnavalescos mantuvieron las tendencias a la libertad y la igualdad su última y testimonial victoria sobre las opresiones sociales. Y tanto las imágenes verbales como las gestuales formaron parte:

del conjunto carnavalesco estructurado en base a una lógica unitaria. Este conjunto es el drama cómico, que abarca a la vez la muerte del viejo mundo y el nacimiento del nuevo. Cada una de las imágenes por separado está subordinada a este sentido único y refleja la concepción del mundo unitaria que se forma en las contradicciones, aunque la imagen exista aisladamente. En su participación en este conjunto, cada una de estas imágenes es profundamente ambivalente: tiene una relación muy importante con el ciclo vida-muerte-nacimiento ${ }^{60}$.

57 Mijail BAjTIN, La cultura popular en la Edad Media y en el Renacimiento. El contexto de François Rabelais (Madrid: Alianza, 1990), pp. 74-75.

58 Ibid., p. 196.

59 Ibid., pp. 190 y 241.

60 Ibid., p. 135. 
Teniendo en cuenta las consideraciones de Bajtin respecto a que las fiestas oficiales de la Edad Media contribuían a sancionar y fortificar el régimen vigente, y si se servían del pasado era "para consagrar el orden social presente [...] A diferencia de la fiesta oficial, el Carnaval era el triunfo de una especie de liberación transitoria, la abolición provisional de las relaciones jerárquicas, privilegios, reglas y tabúes [...] En las fiestas oficiales las distinciones jerárquicas se destacaban a propósito [...] Esta fiesta tenía por finalidad la consagración de la desigualdad ${ }^{6}{ }^{6}$. Las anteriores propuestas de Bernheimer, Heers, Caro Baroja y otros autores: ¿se puede estructurar un sistema de transformaciones que recoja las diferentes relaciones de oposición presentes en las sucesivas formas adoptadas por los rituales de conquista en España? Podría ser así:

\begin{tabular}{|c|c|c|c|}
\hline Ámbito & VENCEDOR & Vencido & Metáfora \\
\hline & * VIDA & Muerte ${ }^{*}$ & Lo nuevo-lo viejo \\
\hline Naturalístico & VERANO & Invierno & Flores-heno, paja \\
\hline & ${ }^{*}$ BIEN & Mal * & \\
\hline Moral / & VIRTUDES & Pecados & \\
\hline & ÁNGELES & Demonios & Cielo-infierno \\
\hline & SANTO & Dragón & \\
\hline & ${ }^{*}$ CULTURA & Naturaleza * & \\
\hline Socio-cultural \} & DOMADOR & Oso & \\
\hline & CABALLERO & Salvaje & Artificial-brutal \\
\hline & DAVID & Goliat & Pequeño-grande \\
\hline Étnico-religioso / & CRISTIANOS & Moros & Poderoso-impotente \\
\hline & ESPAÑOLES & Extranjeros & \\
\hline $\begin{array}{l}\text { (normas, } \\
\text { seried }\end{array}$ & $\begin{array}{r}\text { idad, Control } \\
\text { iia, gobierno, } \\
\text { lez, habitual) } \\
\text { Trabajo }\end{array}$ & $\begin{array}{l}\text { LIBERTAD, } \\
\text { (licencias, ig } \\
\text { grotesco, ero } \\
\text { FIESTA }\end{array}$ & $\begin{array}{l}\text { JAL } \\
\text { locura, } \\
\text { coráneoo) }\end{array}$ \\
\hline
\end{tabular}

No es fácil demostrar el encadenamiento de los eslabones más primitivos en en este sistema de transformaciones de los rituales de conquista, pero creo que existen indicios que justifican su inclusión.

De las luchas estacionales en sí no constan referencias que las integren directamente a este universo festivo en España. Pero todavía se conserva un ritual festivo en la procesión del Corpus de Béjar (Salamanca), antiguo núcleo pastoril fortificado, que puede servir como prueba: escoltan la bandera de la villa en su acto de rendición ante el Santísimo Sa-

61 Ibid., p. 15. 
cramento" un grupo de hombres con porras, cubiertos de musgo arrancado de las peñas de la cercana sierra. La explicación que los vecinos dan actualmente es que con el musgo y las ramas se camuflaron los cristianos para conquistar la población a los moros en la Edad Media.

Hasta hace unas décadas, cuando la procesión del Corpus atravesaba la puerta principal de la muralla, llamada "Puerta de los osos", el tropel de hombres de musgo, simulando ser osos, atacaban la entrada, defendida por una guardia mora. Después de reñido combate, se rendían los moros, y flanqueados por los cristianos de musgo se integraban a la comitiva procesional. En los archivos municipales se guarda un informe redactado en 1735 para rastrear el origen del ritual. En él se dice que lo que se conmemora es la hazaña de "católicos y animosos corazones [que] vistiéndose de pieles y representando diversos animales feroces, saliendo del poblado y antiguo monte de gruesos castaños [se introdujeron] en esta villa degollando sus centinelas" y rescatándola para el cristianismo ${ }^{62}$. Aquí se tiene pues, una legendaria soldadesca de hombres de musgo que luchaba contra los moros simulando ser osos para conquistar el pueblo.

Respecto al musgo como elemento simbólico, en España sigue siendo utilizado por los niños de Castrocaldelas (Orense) para disfrazarse como mayos vivientes en la fiesta del $10^{\circ}$ de mayo, que refleja la recuperación de la vegetación tras el invierno. Y en Europa, en un ritual de la región media del Rhin, un representante del invierno con capa de paja o musgo combatía contra un representante del verano cubierto de yedra, quien siempre resultaba vencedor ${ }^{63}$. Por la misma zona, en el s. XIV la máscara de hombre salvaje constaba de "pieles, líquenes y musgo" ${ }^{64}$.

Otros rituales españoles emparentados los encontramos entre las mascaradas invernales. En el pueblo navarro de Lanz se desarrolla una pantomima entre el personaje de un caballo salvaje, que ataca sin cesar a un estrafalario hombre de heno, al que defienden los chachos, mozos enmascarados cubiertos con pieles de animales y armados de palos, quienes terminan por capturar al caballo salvaje y fingen colocarle las herraduras. Aquí la soldadesca invernal domestica a la fiera, en lo que puede ser un desdoblamiento del mismo símbolo. Y a finales del pasado siglo, en Pontevedra se celebraron los carnavales con el desembarco del rey Urco y su desafío y ataque al rey Teucro, legendario fundador de la villa, que

62 Recogido por A. BARRIOS y A. MARTÍN, Documentación medieval de los archivos municipales de Béjar y Candelario (Salamanca: Diputación de Salamanca, 1986), p. 240.

63 James G. Frazer, op. cit., p. 368.

64 Leander PETZOLDT, Los carnavales en la cultura burguesa a comienzos de la Edad Modernan, Uwe SchUltz (ed.), La Fiesta (Madrid: Alianza, 1993), p. 161. 


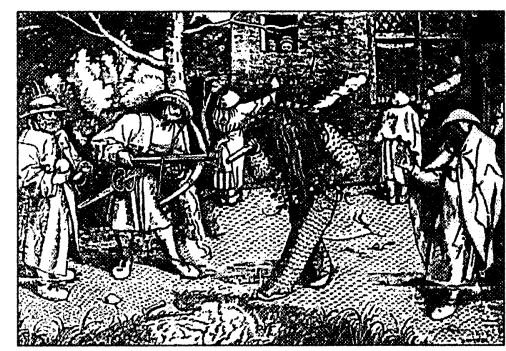

FIG. 9.-El juego carnavalesco de Valentin y el osezno, según grabado de Bruegel (1566).

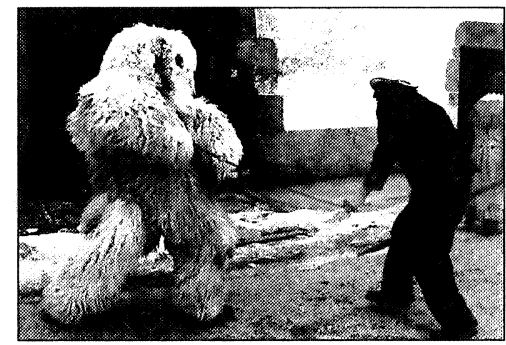

FIG. 11.-Mascarada del oso y su domador, en los carnavales navarros de Lanz.

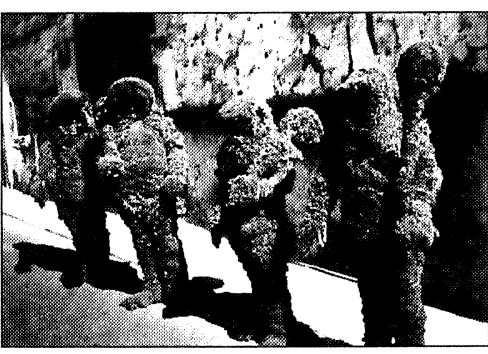

FIG. 10.-Comitiva de los hombres de musgo en la procesión del Corpus de Béjar (Salamanca).

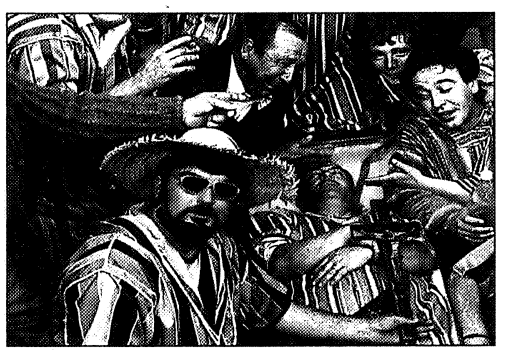

FIG. 12.-Mojiganga del entierro del capitán moro, improvisada por la comparsa mora de los Pacos (Muchamiel, Alicante).

se había refugiado en un castillo. El nombre urco nos recuerda al orcus del "hombre salvaje", y al orcum, el "huerco" o demonio medieval.

En lo que respecta al enfrentamiento entre Virtudes y Pecados, todavía subsiste como danza en las procesiones del Corpus de Camuñas (Toledo) y de Valencia, personificada en ambos sitios la Gracia por un hombre vestido de mujer. Las restantes relaciones de oposición se han ido documentando anteriormente, todas ellas existen o existieron en España.

Finalmente, falta una sola conexión: la caza del oso con el combate contra los moros. Y puede estar en la fiesta del solsticio de verano en Torralba (Navarra), organizada por su "cofradía de arcabuceros", quienes salen al campo a perseguir al caudillo moro Juan Lobo: lo capturan, lo llevan a la plaza en donde es juzgado, sentenciado y muerto a lanzadas. La secuencia dramática es la misma que la de varios peleles carnavalescos y cacerías de osos y hombres salvajes. Pero en este caso se trata de una representación de moros y cristianos en la que el personaje perseguido, el moro, es llamado lobo, una fiera salvaje que puede estar ocupando el lugar del oso. 
Recapitulando, se puede diseñar el siguiente microsistema de imágenes:

$$
\text { INVIERNO }\left\{\begin{array}{l}
- \text { oso } \\
- \text { hombre salvaje } \\
- \text { pelele de fin de año } \\
- \text { moro mítico }
\end{array}\right\} \text { ENEMIGO }
$$

- Todos ellos, representantes del inframundo, víctimas propiciatorias para expulsar las almas de los difuntos y evitar que causen desgracias -

Aún falta otro importantísimo aspecto que considerar. En todas las relaciones de oposición hay un elemento significativo que aparece como motivo de la confrontación: la doncella. Bien se trate del oso, del dragón, los salvajes, los demonios, los pecados, los moros o los extranjeros, el único o al menos uno de sus objetivos es el rapto de la doncella. Si bien en la lucha entre David y Goliat no aparece como tal, de hecho a David se le ofrece la mano de la princesa si vence al gigante. Incluso en el teatro culto religioso es un motivo muy repetido. En el caso del invierno, varias de sus personificaciones persiguen a las mujeres, y al someterles a juicio suelen ser acusados de lascivia, lujuria y deseos sexuales desenfrenados, por lo que son condenados y ajusticiados.

Si analizamos el símbolo de la imagen del santo/a, ese protector celestial de la comunidad, por una parte se puede considerar expresión simbólica de: actividades agríco-civilizadoras, la fertilidad y la vida. Que se pueden asociar en un único concepto, la diosa del saber y el placer. Y da igual quién la rapta, si el dragón, el demonio u otros hombres (en buen número de localidades, la Virgen María es raptada por los moros), el hecho cierto es que será dominada por el guerrero y todopoderoso padre-dios, la otra parte constitutiva del santo, construcción mental del género masculino. Y quizás sea ésta la fechoría básica que ritualmente se representa ante un público en su mitad compuesto por mujeres, el "otro" de "los héroes y sus enemigos", como lección histórica no olvidable: han sido conquistadas. Y esta captura del poder femenino resulta que, bajo la forma de "rapto de la doncella por el dragón", también es el tema básico de los cuentos folklóricos maravillosos (Propp), por lo que se comprueba su arraigo en uno de los más profundos sustratos del inconsciente colectivo. La paulatina incorporación de las mujeres a estos rituales, propia de nuestro siglo y especialmente a partir de los setenta, es una consecuencia de la recuperación de parte de su autonomía social, y así se está modificando uno de los mensajes simbólicos trasmitidos por estos rituales.

Y para acabar con este apartado, una hipótesis sobre la fiesta de conquista más antigua de España. En el primer libro de historia española, la 
General Estoria, mandada redactar por Alfonso X de Castilla en el s. XIII, se recuerda que, tras derrotar al tirano Gerión, Hércules hizo asus juegos y sus alegrías grandes" por haber vencido ${ }^{65}$. Esta fiesta forma parte de un complejo mítico creado en torno al décimo trabajo de Hércules: retar y matar a los reyes de Iberia, los Geriones, para robarles el ganado y conquistar el territorio ${ }^{66}$. Según el mito, esta batalla tuvo lugar en los Montes Tartesios, cerca de la boca del estrecho de Gibraltar, y fue conocida como "la guerra entre los dioses y los titanes o gigantes", recayendo el mérito de matar al jefe de los titanes, sucesivamente en Osiris, Dionisio, Baco o su hijo Hércules, ya que se les fue asimilando al mismo vencedor personaje divino. Es sabido que Cádiz es la ciudad más antigua de Occidente y en sus cercanías se levantaba el templo del Hércules Egipcio, donde se veneraban las cenizas de este poderoso dios solar y marino, y que tuvo gran fama en la Antigüedad, hasta que en el año 384 se prohibieron los sacrificios alli ${ }^{67}$. Dado el buen número de ruinas de teatros griegos y romanos que se esparcen por la Península Ibérica, y la afición de los lugareños por el teatro, no sería extraño que la mítica batalla entre los dioses y los gigantes hubiera sido escenificada ritualmente. Sabemos que ciertos dragones procesionales españoles se relacionan con la bidra de Lerna que mató Hércules ${ }^{68}$, y que en el recibimiento que le hizo la ciudad de Burgos en 1571 a la que venía a desposar a Felipe II, salieron unos "matachines que hacían tales mudanzas, gestos y fuerzas, que dicen de Hércules" ${ }^{69}$. ¿No podría también haber habido unas representaciones de la conquista de Hispania por Hércules que fuesen el modelo formal de los actuales ritos?

Si bien ésto no es demostrable, sí se puede pensar que la oficializada lucha de moros y cristianos, como muy pronto, debe ser del s. XI (la primera cruzada convocada por un Papa fue la de Barbastro, en Aragón, en el 1064, mientras que la toma de Jerusalén por los cruzados es en 1099) y se superpuso a un modelo festivo épico-militar paralelo a unas mascaradas populares estacionales y de domesticación, casi seguramente anteriores.

65 Jueces, Cap. CDXX. El lugar de la fiesta se sitúa en Lucena (Córdoba).

66 Según cuenta DIODORO DE SICILIA, en el siglo I.

67 José M. ${ }^{a}$ BLÁzQUEZ, Imagen y mito. Estudio sobre religiones mediterráneas e ibéricas (Madrid: Ed. Cristiandad, 1977), p. 27.

68 J. CARO BAROJA, op. cit., 1984, p. 85.

69 ANÓNIMO, Relación verdadera, del re/cebimiento, que la muy N. y muy / más leal ciudad de Burgos, cabeza de / Castilla [...] bizo a la reyna $N .^{a}$ S. ${ }^{a}$ Doña Ana de Austria (Burgos, 1571). 


\section{REPERCUSIÓN DE LOS RITUALES MEXICANOS EN ESPAÑA}

Es asumible que el proceso de trasmisión de estas representaciones rituales tuviera doble sentido, y que por un "feed-back" comunicativo, la metrópoli a su vez hubiera sido influida por rituales festivos indoamericanos. Desgraciadamente, es muy escaso el material localizado en España sobre este aspecto.

En primer lugar, tenemos que la inicial visión del otro americano (antillanos, mexicas) se adaptó por los españoles al estereotipo imaginario del hombre salvaje, para configurarse luego como los indios, que abarcaba genéricamente a todas las culturas del Nuevo Mundo. En tiempos de Felipe II comenzaron a incluirse las danzas de indios dentro de las procesiones religiosas, como en la fiesta de la Asunción de la Virgen en Toledo en 1585, en la que llevaban el rostro dorado y vestían telas de oro y plata, con espejos en el pecho, joyas en los dedos y plumas, acompañados por un mono iy un elefante! ${ }^{70}$ Comenzaron también a ser representados por parejas de los gigantes del Corpus, y la visión alegórica culminó en los propios autos sacramentales, como en una representación de conquista de Calderón de la Barca en la que los enemigos son "la Secta de Mahoma, la Apostasía y la Idolatría (vestida a lo indio)” ${ }^{71}$.

En segundo lugar, ciertos elementos formales fueron trasplantados, como decoraciones escenográficas. En la fiesta por la beatificación de San Isidro celebrada en Madrid en 1620, en su Plaza Mayor se levantó el castillo de la perfección que debía conquistar el santo, sobre un decorado que simulaba una montaña con grutas, riscos, árboles, flores, animales fingidos y reales ${ }^{72}$, lo que recuerda bastante los simulacros de bosques y montañas artificiales con variedad de animales vivos con los que en el México prehispánico se adornaban las plazas de los mercados o de los templos para los grandes festejos, como los del dios de la lluvia Tláloc descrito por el P. Durán ${ }^{73}$. Otro elemento formal, una máscara con un

70 Emilio COTARELO Y MORI: Colección de entremeses, loas, bailes, jácaras y mojigangas (Madrid: NBAE, 1911), p. CLXXIII.

${ }^{71}$ Titulado El cubo de la Almudena, ensalza el apoyo de la Virgen patrona de Madrid para vencer a los moros. Editado en 1717.

72 ANÓNImo, Relación de las fiestas de la beatificación de San Isidro, en J. Simón DiAZ, Relaciones de actos públicos celebrados en Madrid (1541-1650) (Madrid: Inst. de Estudios Madrileños, 1982), pp. 114-118.

73 "Parecía cosa natural y no compuesta y fingida", dice Fray Diego Durán, Historia de las Indias de Nueva España e Islas de la Tierra Firme (México D. F.: Ed. Porrúa, 1967), t. I, cap. VIII, p. 86. 
gran abanico circular en lo alto, que se asemeja a las coronas de los danzantes de la pluma de Oaxaca y de los quetzales de Puebla, es usada actualmente por los guirrias o domadores de toros en carnavales leoneses.

Finalmente, conozco tres danzas de la conquista de México celebradas en España y de gran interés. Una es muy conocida: el recibimiento que la villa de Alcalá de los Gazules (Cádiz) en 1571 tributó a su Señor Duque, con la escenificación de la Prisión de Moctezuma (en la que intervinieron 200 hombres disfrazados de indios) con la embajada de Cortés y la batalla en la que Moctezuma y sus caciques fueron derrotados. Al día siguiente, el festejo consistió en una farsa de moros y cristianos, con cautiverio de una doncella. Ambos espectáculos denotan la habilidad de un autor-organizador de fiestas, pudiendo tratarse de Juan de la Cueva, que a la sazón tendría 21 años. Este sevillano, vinculado al mecenazgo cultural del duque de Alcalá, acreditó su interés por las Indias al residir en la Nueva España entre 1574-77. Allí asistió a unos mitotes y danzas de los que escribió que "en sus cantos endechan el destino/ de Moctezuma, la prisión y la muerte/ maldiciendo a Malinche y su camino./ Al gran marqués del Valle llaman fuerte/ que los venció; llorando desto, cuentan/ toda la guerra y su contraria muerte" ${ }^{74}$. En dicho período maduró su concepción dramatúrgica, ya que poco después de su regreso estrenó en Sevilla Los siete infantes de Lara, obra de Moros y Cristianos basada en un impactante reto del romancero viejo, como luego hizo con el Reto de Zamora y Bernardo del Carpio. Este precursor de las comedias del Siglo de Oro español se considera que fue el primero en introducir reyes y reinas en los corrales de comedias. Por lo que las representaciones de conquista americanas pudieron haber influído en la evolución del teatro hispano a través de su pluma.

A los pocos meses de la fiesta de Alcalá, para festejar en la corte de Madrid el nacimiento de un hijo de Felipe II, conquistadores españoles indianos engalanados a caballo:

hicieron la entrada y salida acompañando al rey Moctezuma y a su mujer, que fueron príncipes señalados en las Indias, y venían en sendas andas traídas por hombres vestidos como indios casi en número de ciento, todos sus arcos y flechas muy en orden y vistosos [sacaron muchas riquezas y fue una fiesta] muy de ver y muy concertada en las carreras que corrieron y cañas que jugaron y a parecer y juicio de muchos, la mejor que se haya hecho muchos días ha en esta corte ${ }^{75}$.

No se aclara si hubo desafíos, aunque es posible.

74 En Poetas novohispanos, cit. por María STEN, Vida y muerte del teatro nabuatl (México D. F.: SepSetentas, 1974) p. 104.

75 Ibid., p. 83, citando los Documentos para la bistoria de México en colecciones austriacas. 
Y para terminar, la exaltación al trono del rey Fernando VI en 1747 fue celebrada en Sevilla por la "nación gitana" con una máscara joco-seria sobre la Toma de México y prisión de su emperador Moctezuma, en la que intervenían ridículas danzas a pie y en burros, la Danza de Mozas Grandes que "con gran primor danzaban, como indias de aquel tiempo, la Danza de Motezuma, que era oirla gran recreo" y un carro con la escenificación en vivo de Hernán Cortés y sus soldados rindiendo al Emperador de México, al que seguían seis indios a caballo con sus flechas y carcaj ${ }^{76}$. Los marginados gitanos sevillanos, imitando una danza mexicana e identificándose simbólicamente con los conquistadores, nos aportan la clave interpretativa final: la compensación o satisfacción simbólica que puede recibir un grupo humano socialmente oprimido cuando se convierte en protagonista por delegación de una épica conquista ${ }^{77}$.

\section{DEMETRIO E. BRISSET}

Departamento de Comunicación Audiovisual Facultad de Ciencias de la Información Universidad de Málaga

Hay un vasto complejo festivo ritual que ha tenido y sigue teniendo gran popularidad en la cultura hispánica: el de las teatralizadas representaciones de la conquista de un bando sobre otro. Con el fin de interpretar su más profundo significado, se delimitará y someterá a un estudio comparativo morfológico, histórico y cultural (en la línea desarrollada por Caro Baroja), en busca de las diversas influencias que, a lo largo de muchos siglos, lo han ido transformando, hasta ocultar sus mensajes originarios.

There is a vast ritualized festive complex which was, and still is, very popular in Hispanic culture, that of the dramatized representations of wars of conquest. In order to unravel their deep significance, the author first defines and then discusses these representations comparatively at various levels - morphological, historical, and cultural-, along the lines developed by J. Caro Baroja. He aims at identifying the different influences which have transformed this festive complex over the centuries, to the point of concealing its original messages.

76 Según la relación de un testigo presencial, en Tomás AlENDA, Solemnidades y fiestas públicas de España (Madrid, 1903), II, p. 51.

77 Agradezco al Consejo Nacional para la Cultura y las Artes de México su ayuda para la redacción de este ensayo, y al Ministerio de Asuntos Exteriores de la República de México por la concesión de la Beca "Jenaro Estrada" que me permitió realizar alli un trabajo de campo durante dos meses. También agradezco las sugerencias y críticas de los Dres. Julio Caro Baroja, José Luis García, Jesús Jáuregui, Carlo Bonfiglioli y Manuela Cantón. 